Check for updates

Cite this: J. Mater. Chem. A, 2019, 7, 12303

Received 25th January 2019

Accepted 8th April 2019

DOI: $10.1039 / c 9 t a 00957 d$

rsc.li/materials-a

\title{
Deep eutectic solvent route synthesis of zinc and copper vanadate $n$-type semiconductors - mapping oxygen vacancies and their effect on photovoltage $\dagger$
}

\begin{abstract}
Sangki Hong, ${ }^{a}$ Rachel M. Doughty, (DD b Frank E. Osterloh (D) ${ }^{b}$ and Julia V. Zaikina (D) *a
Ternary metal oxides $\mathrm{M}_{2} \mathrm{~V}_{2} \mathrm{O}_{7-\delta}(\mathrm{M}=\mathrm{Zn}$ and $\mathrm{Cu}$ ) were synthesized by dissolving binary metal oxide precursors in an environmentally benign deep eutectic solvent (DES), which is a eutectic mixture of a hydrogen bond donor and acceptor, followed by annealing in an open crucible. The unique reaction environment provided by the evolved ammonia allows for stabilization of oxygen vacancies and reduced oxidation states of metal ions within an oxide matrix without the need for any post-treatment with flammable reducing agents. According to comprehensive characterization, including $X$-ray photoelectron spectroscopy (XPS), neutron powder diffraction, and UV-vis spectroscopy, oxygen deficiency is accompanied by reduced oxidation states of metal centers $\left(\mathrm{Cu}^{+}\right.$or $\left.\mathrm{V}^{4+}\right)$, resulting in oxides with mixed-valence metal oxidation states. The amount of oxygen vacancies can be tuned by changing the annealing temperature providing control over band gaps of ternary metal oxides and mid-gap states from reduced metal centers. All synthesized vanadates are $n$-type semiconductors based on negative photovoltages obtained from surface photovoltage spectroscopy (SPS). A decay of the photovoltage with increasing annealing temperatures is attributed to electron trapping and electron/hole recombination at $\mathrm{V}^{4+}$ and $\mathrm{Cu}^{+}$mid-gap states. This work shows for the first time the impact of oxygen vacancies on the electronic structure of DES synthesized oxides for solar energy conversion applications.
\end{abstract}

\section{Introduction}

Since the discovery of photoelectrochemical (PEC) water oxidation with $\mathrm{TiO}_{2},{ }^{1}$ research on semiconducting metal oxide photocatalysts has been growing. Other $\mathrm{d}^{0}$ binary metal oxides containing $\mathrm{Zr}^{4+}, \mathrm{Nb}^{5+}, \mathrm{Ta}^{5+}$, and $\mathrm{W}^{6+}$ have been studied due to their photocatalytic properties. ${ }^{2-13}$ However, their wide bandgaps limit absorption of visible-light, which is a major part of the solar spectrum at the surface of the earth. Ternary metal oxides are attractive candidates for solar PEC applications because their crystal and, consequently, electronic structure can be modified by introducing an additional metal. ${ }^{13}$ For example, $\mathrm{SnNbO}_{6}$ with a band gap of $2.3 \mathrm{eV}$ exhibits improved photocatalytic activity for hydrogen evolution under visible light irradiation with Pt loading. ${ }^{14} \mathrm{Fe}_{2} \mathrm{~V}_{4} \mathrm{O}_{13}$ was found to have a narrow band gap of $1.83 \mathrm{eV}$ and show high efficiency in photoreduction of $\mathrm{CO}_{2}$ to hydrocarbon fuels. ${ }^{15}$

${ }^{a}$ Department of Chemistry, Iowa State University, Ames, Iowa 50011, USA. E-mail: yzaikina@iastate.edu

${ }^{b}$ Department of Chemistry, University of California at Davis, Davis, California 95616, USA

$\dagger$ Electronic supplementary information (ESI) available. See DOI: $10.1039 / \mathrm{c} 9 \mathrm{ta} 00957 \mathrm{~d}$
Oxygen vacancies play a central role in optical absorption, transport properties, and photocatalytic performance of oxide materials. For example, $\mathrm{SrTiO}_{3}$ photoelectrodes must be annealed in a hydrogen atmosphere at $1050{ }^{\circ} \mathrm{C}$ in order to produce the desired semiconducting behavior for water oxidation. ${ }^{16}$ Similarly, hydrogenated $\mathrm{TiO}_{2}$ can be prepared by heat treatment of white $\mathrm{TiO}_{2}$ in 20 bar $\mathrm{H}_{2}$ at $200{ }^{\circ} \mathrm{C}$ for 5 days. ${ }^{17}$ This oxygen-defective $\mathrm{TiO}_{2-\delta}$ exhibits improved UV photocatalytic activity for hydrogen evolution from aqueous solutions of sacrificial electron donors. Hydrogen-treated $\mathrm{WO}_{3}$ and $\mathrm{BiVO}_{4}$ with oxygen vacancies exhibit enhanced catalytic activity for photoelectrochemical water oxidation. ${ }^{18,19}$

Recently, copper vanadates were reported to be a potential photoanode candidate for the visible-light driven water splitting reaction. ${ }^{20-24}$ In the electronic structure of $\beta-\mathrm{Cu}_{2} \mathrm{~V}_{2} \mathrm{O}_{7}$ the valence band maximum (VBM) and conduction band minimum (CBM) are dominated by $\mathrm{O} 2 \mathrm{p}$ and $\mathrm{Cu} 3 \mathrm{~d}$ orbitals respectively. ${ }^{22}$ The partially filled d-subshell of copper improves visible light absorption and photocurrent for the oxygen evolution reaction. ${ }^{20-23}$ Interestingly, $\alpha-\mathrm{Zn}_{2} \mathrm{~V}_{2} \mathrm{O}_{7}$ and $\beta-\mathrm{Cu}_{2} \mathrm{~V}_{2} \mathrm{O}_{7}$ belong to the family of $\mathrm{M}_{2} \mathrm{~V}_{2} \mathrm{O}_{7}(\mathrm{M}=\mathrm{Zn}$ and $\mathrm{Cu})$ with similar monoclinic structures. Both compounds also resemble each other in that they have $\mathrm{O} 2 \mathrm{p}$ as the main contribution to the valence band 
maximum (VBM). ${ }^{22,25}$ However, the conduction band of $\alpha$ $\mathrm{Zn}_{2} \mathrm{~V}_{2} \mathrm{O}_{7}$ predominantly consists of $\mathrm{V} 3 \mathrm{~d}$ orbitals due to the completely filled d-subshell of zinc. ${ }^{25}$ To the best of our knowledge, a systematic study on $\mathrm{M}_{2} \mathrm{~V}_{2} \mathrm{O}_{7}(\mathrm{M}=\mathrm{Zn}$ and $\mathrm{Cu})$ has not been reported.

In this work, $\alpha-\mathrm{Zn}_{2} \mathrm{~V}_{2} \mathrm{O}_{7-n}$ and $\beta-\mathrm{Cu}_{2} \mathrm{~V}_{2} \mathrm{O}_{7-m}$ were prepared by reaction in a deep eutectic solvent (DES), which is a eutectic mixture of a hydrogen bond donor (urea) and acceptor (choline chloride) in a $2: 1$ molar ratio. ${ }^{26-28}$ This synthetic route includes dissolution of binary oxides in an environmentally friendly and benign eutectic mixture followed by heat treatment in air. High solubility of binary metal oxides in the DES and fast mixing of the metal precursors are attractive features of this synthetic method, which also provide control over the size and composition of the products and concentration of oxygen vacancies. Moreover, this route does not require flammable reducing agents and/or a complex experimental set-up for post-treatment. Thermal stability and synthesis optimization of $\alpha-Z_{2}$ $\mathrm{V}_{2} \mathrm{O}_{7-n}$ and $\beta-\mathrm{Cu}_{2} \mathrm{~V}_{2} \mathrm{O}_{7-m}$ were studied, and band gap modification by oxygen vacancies was investigated. The impact of oxygen vacancies on the generation of a surface photovoltage under visible light is discussed.

\section{Experimental}

\section{Materials synthesis}

Urea (Alfa, 99\%, crystalline), $\mathrm{ZnO}$ (Alfa, 99.9\%), $\mathrm{Cu}_{2} \mathrm{O}$ (Alfa, 99.9\%), and $\mathrm{V}_{2} \mathrm{O}_{5}$ (Alfa, 99.6\% min) were used as received without any further purification. Choline chloride (SigmaAldrich, $\geq 98 \%$ ) was dried at $120^{\circ} \mathrm{C}$ under vacuum prior to use. A deep eutectic solvent (DES) was prepared by mixing urea and choline chloride in a $2: 1$ molar ratio (54.322 $\mathrm{g}$ urea and $63.750 \mathrm{~g}$ choline chloride for $\alpha-\mathrm{Zn}_{2} \mathrm{~V}_{2} \mathrm{O}_{7}$ and $55.200 \mathrm{~g}$ urea and $64.800 \mathrm{~g}$ choline chloride for $\left.\beta-\mathrm{Cu}_{2} \mathrm{~V}_{2} \mathrm{O}_{7}\right)$. The mixture was heated at $70{ }^{\circ} \mathrm{C}$ in a parafilm-covered glass beaker with stirring until a homogeneous liquid was obtained. Each metal precursor (0.567 $\mathrm{g} \mathrm{ZnO}$ and $0.633 \mathrm{~g} \mathrm{~V}_{2} \mathrm{O}_{5}$ for $\alpha-\mathrm{Zn}_{2} \mathrm{~V}_{2} \mathrm{O}_{7}$ and $0.506 \mathrm{~g} \mathrm{Cu}_{2} \mathrm{O}$ and $0.644 \mathrm{~g} \mathrm{~V}_{2} \mathrm{O}_{5}$ for $\beta-\mathrm{Cu}_{2} \mathrm{~V}_{2} \mathrm{O}_{7}$ ) was dissolved in a separate beaker containing the DES under vigorous stirring at $70{ }^{\circ} \mathrm{C}$. The concentration of $\mathrm{ZnO}, \mathrm{Cu}_{2} \mathrm{O}$, and $\mathrm{V}_{2} \mathrm{O}_{5}$ was $0.06986 \mathrm{M}, 0.03493 \mathrm{M}$, and $0.03493 \mathrm{M}$, respectively. The solutions with the dissolved precursors were further mixed ( $\mathrm{ZnO}$ and $\mathrm{V}_{2} \mathrm{O}_{5}$ for $\alpha-\mathrm{Zn}_{2} \mathrm{~V}_{2} \mathrm{O}_{7}$ and $\mathrm{Cu}_{2} \mathrm{O}$ and $\mathrm{V}_{2} \mathrm{O}_{5}$ for $\beta$ $\mathrm{Cu}_{2} \mathrm{~V}_{2} \mathrm{O}_{7}$ ) and left stirring at $70{ }^{\circ} \mathrm{C}$ overnight with a parafilm cover. Afterwards, the solutions (light green for $\alpha-\mathrm{Zn}_{2} \mathrm{~V}_{2} \mathrm{O}_{7}$ and dark blue for $\beta-\mathrm{Cu}_{2} \mathrm{~V}_{2} \mathrm{O}_{7}$ ) were transferred to porcelain crucibles for calcination ( $7 \mathrm{~mL}$ of solution in $30 \mathrm{~mL}$ crucibles). A heat treatment was performed in open crucibles, in air using a muffle furnace (box-type). A heating rate of $10{ }^{\circ} \mathrm{C} \mathrm{min}^{-1}$ was employed. For $\alpha-\mathrm{Zn}_{2} \mathrm{~V}_{2} \mathrm{O}_{7}$, the precursor solution was heated at $230{ }^{\circ} \mathrm{C}$ for 2 hours and then calcined at $500{ }^{\circ} \mathrm{C}, 600{ }^{\circ} \mathrm{C}$, or $700{ }^{\circ} \mathrm{C}$ for a span of 10.5 hours $\left(500^{\circ} \mathrm{C}\right)$ or 12 hours $\left(600^{\circ} \mathrm{C}\right.$ and $700{ }^{\circ} \mathrm{C}$ ). For $\beta-\mathrm{Cu}_{2} \mathrm{~V}_{2} \mathrm{O}_{7}$, the precursor solution was heated at $300{ }^{\circ} \mathrm{C}$ for 7 hours and then calcination was carried out at 400 ${ }^{\circ} \mathrm{C}$ or $500{ }^{\circ} \mathrm{C}$ for 7 hours. About $27 \mathrm{mg}$ of $\alpha-\mathrm{Zn}_{2} \mathrm{~V}_{2} \mathrm{O}_{7}$ (76\% yield) and $32 \mathrm{mg}$ of $\beta-\mathrm{Cu}_{2} \mathrm{~V}_{2} \mathrm{O}_{7}$ (72\% yield) powdered products were obtained. Different colors were observed for samples annealed at different temperatures: pale yellow $\left(500{ }^{\circ} \mathrm{C}\right) /$ grey $\left(600{ }^{\circ} \mathrm{C}\right) /$ light pink $\left(700{ }^{\circ} \mathrm{C}\right)$ for $\alpha-\mathrm{Zn}_{2} \mathrm{~V}_{2} \mathrm{O}_{7}$ and orange $\left(400{ }^{\circ} \mathrm{C}\right) /$ dark red $\left(500{ }^{\circ} \mathrm{C}\right)$ for $\beta-\mathrm{Cu}_{2} \mathrm{~V}_{2} \mathrm{O}_{7}$.

\section{Characterization}

Powder X-ray diffraction. Samples were characterized by powder X-ray diffraction (PXRD) using a Rigaku Miniflex 600 diffractometer with $\mathrm{Cu} \mathrm{K} \alpha$ radiation $(\lambda=1.54051 \AA)$. Diffraction scans were collected from 5 to $90^{\circ} 2 \theta$ on a zero-background plate at room temperature in air. Phase identification was performed with the PDF-2 database using PDXL software. ${ }^{29}$

In situ synchrotron powder $\mathrm{X}$-ray diffraction. Variable temperature synchrotron powder X-ray diffraction data were collected at the synchrotron beamline 17-BM at the Advanced Photon Source (APS), Argonne National Laboratory (ANL). Precalcined samples were loaded into silica capillaries $(0.5 \mathrm{~mm}$ inner diameter and $0.7 \mathrm{~mm}$ outer diameter), which were placed inside a secondary shield capillary in a flow furnace. A thermocouple was set as close as possible to the sealed end of the inner silica capillary, and $20 \%$ oxygen gas in helium gas was flowed into the open end of the inner silica capillary during the measurement. The data were collected with $\lambda=0.24128 \AA$ in a temperature range from $23{ }^{\circ} \mathrm{C}$ to $800{ }^{\circ} \mathrm{C}$ with a heating rate of $20{ }^{\circ} \mathrm{C} \mathrm{min}^{-1}$. More details regarding the experimental setup can be found elsewhere. ${ }^{30}$ Temperature calibration was applied by calibration using the melting points of elemental Sn, Sb, and Ge.

Scanning electron microscopy and energy dispersive spectroscopy. Scanning electron microscopy (SEM) was performed using a FEI Quanta 250 field emission SEM at $15 \mathrm{kV}$. Energy dispersive X-ray spectroscopy (EDS) was performed using an Oxford X-Max 80 detector for elemental composition analysis. Powdered samples were deposited on a SEM sample holder using carbon tape, followed by coating with $5 \mathrm{~nm}$ of iridium metal.

Diffuse reflectance UV-vis spectroscopy. Diffuse reflectance UV-vis spectra were collected using a BLACK-Comet C-SR-100 spectrometer equipped with a SL1 tungsten halogen lamp (visIR) and a SL3 deuterium lamp (UV). Compacted samples were prepared on glass slides by flattening the solids with a metal spatula. Indirect bandgap values for samples were estimated by extrapolating the linear slope of Tauc plots by plotting $(\alpha \times h \nu)^{1 / 2}$ $v s$. $h \nu$, where $\alpha$ is absorption and $h \nu$ is the excitation energy in $\mathrm{eV}$.

Differential scanning calorimetry (DSC) and thermogravimetric analysis (TGA). DSC/TGA measurements were taken using a Netzsch STA449 F1 Jupiter coupled with a Netzsch quadrupole mass spectrometer 403 D Aeolos and a Bruker Tensor 37 FTIR spectrometer. Zinc vanadate and copper vanadate samples for DSC/TG were previously calcined at $500{ }^{\circ} \mathrm{C}$ and $400{ }^{\circ} \mathrm{C}$, respectively, using the temperature profile described in the Materials synthesis section. Approximately $5 \mathrm{mg}$ of sample was loaded into an alumina crucible with an alumina cover. The sample was heated from $40{ }^{\circ} \mathrm{C}$ to $950{ }^{\circ} \mathrm{C}$ and cooled from $950{ }^{\circ} \mathrm{C}$ to $310{ }^{\circ} \mathrm{C}$ with a ramp/cooling rate of $10^{\circ} \mathrm{C} \mathrm{min}{ }^{-1}$. The experiments were performed under a constant gas flow of $20 \% \mathrm{O}_{2}$ and $80 \% \mathrm{~N}_{2}$.

X-ray photoelectron spectroscopy (XPS). XPS measurements were performed using a Kratos Amicus/ESCA 3400 instrument. 
The sample was irradiated with $240 \mathrm{~W}$ non-monochromated $\mathrm{Mg}$ $\mathrm{K} \alpha \mathrm{X}$-rays, and photoelectrons emitted at $0^{\circ}$ from the surface normal were energy analyzed using a DuPont type analyzer. The pass energy was set at $150 \mathrm{eV}$. CasaXPS was used to process raw data files and either a Shirley or linear baseline was applied to the spectra. The adventitious $\mathrm{C} 1 \mathrm{~s}$ set to a binding energy of $284.8 \mathrm{eV}$ was used for charge correction of XPS spectra. The \% concentration of "oxygen defects", $\mathrm{V}^{4+}$ and $\mathrm{Cu}^{+}$was calculated as the ratio of the peak areas: the peak with the binding energy, corresponding to the species in question (e.g. O defects, $\mathrm{V}^{4+}$, and $\mathrm{Cu}^{+}$) over the sum of the peak areas for "oxygen defects" and lattice oxygen, or $\mathrm{V}^{4+}$ and $\mathrm{V}^{5+}$, or $\mathrm{Cu}^{2+}$ and $\mathrm{Cu}^{+}$.

High-resolution synchrotron powder X-ray diffraction (HR SPD). High-resolution synchrotron powder X-ray diffraction data were collected at $295 \mathrm{~K}$ using beamline 11-BM at the Advanced Photon Source (APS), Argonne National Laboratory using an average wavelength of $0.412749 \AA$. Discrete detectors covering an angular range from -6 to $16^{\circ} 2 \theta$ are scanned over a $34^{\circ} 2 \theta$ range, with data points collected every $0.001^{\circ} 2 \theta$ at a scan speed of $0.01^{\circ} \mathrm{s}^{-1}$. Rietveld refinement was performed using GSAS software. ${ }^{31}$

Neutron powder diffraction (NPD). Time-of-flight NPD was performed on a POWGEN diffractometer at the Spallation Neutron Source in Oak Ridge National Laboratory. The diffraction data were collected at $298 \mathrm{~K}$ using neutron beams with wavelengths of $0.8 \AA$ and $2.665 \AA$ for $d$-spacing ranges of 0.40-5.66 $\AA$ and 1.08-5.57 $\AA$, respectively. $495 \mathrm{mg}$ sample was loaded into a vanadium can (6 $\mathrm{mm}$ inner diameter). Rietveld refinement was performed using GSAS software. ${ }^{31}$

Surface photovoltage spectroscopy (SPS) measurements. SPS data were obtained using the vibrating Kelvin probe method. Here a gold mesh reference probe was mounted approximately $1.0 \mathrm{~mm}$ above the sample film and controlled with a Kelvin control 07 unit (Delta PHI Besocke, Germany). The samples were illuminated with monochromatic light from a $150 \mathrm{~W}$ Xe lamp filtered through an Oriel Cornerstone 130 monochromator (0.1-0.3 $\left.\mathrm{mW} \mathrm{cm}^{-2}\right)$. The spectra were corrected for drift effects by subtracting a dark scan.

Sample preparation for SPS. Fluorine-doped tin oxidecoated glass (FTO) substrates for surface photovoltage measurements were sonicated in acetone and water for 3 hours each to remove any surface impurities. Sample powders were suspended in $\mathrm{H}_{2} \mathrm{O}$ at a concentration of $5 \mathrm{mg} \mathrm{mL} \mathrm{m}^{-1}$ and sonicated for 15 minutes. Then $0.1 \mathrm{~mL}$ solution of each sample was deposited dropwise onto a $1 \mathrm{~cm}^{2}$ area on a cleaned substrate and dried uncovered in air. The $\beta-\mathrm{Cu}_{2} \mathrm{~V}_{2} \mathrm{O}_{7}$ films were annealed at $400{ }^{\circ} \mathrm{C}$ for 2 hours in air with a slow ramp of $2{ }^{\circ} \mathrm{C}$ $\min ^{-1}$. To remove possible $\mathrm{V}_{2} \mathrm{O}_{5}$ impurities after annealing, the films were dipped in $0.1 \mathrm{M} \mathrm{NaOH}$ solution at $\mathrm{pH}=13$ for 30 minutes with careful stirring, rinsed in $\mathrm{H}_{2} \mathrm{O}$, and dried in air. SPS measurements were then performed in air. $\alpha-\mathrm{Zn}_{2} \mathrm{VO}_{2} \mathrm{O}_{7}$ films were pre-annealed on a hotplate at $250{ }^{\circ} \mathrm{C}$ for 3 minutes in air and then slowly $\left(2{ }^{\circ} \mathrm{C} \mathrm{min}^{-1}\right)$ heated up to $500{ }^{\circ} \mathrm{C}$ in air and the temperature was maintained for 2 hours. SPS measurements of these samples were performed under vacuum $\left(2.5 \times 10^{-4} \mathrm{mbar}\right)$.

\section{Results and discussion}

The monoclinic structures of $\mathrm{M}_{2} \mathrm{~V}_{2} \mathrm{O}_{7}$ vanadates are similar for both metals, $\mathrm{M}=\mathrm{Cu}$ and $\mathrm{Zn}$, and are based on corner-sharing $\mathrm{VO}_{4}$ tetrahedra and $\mathrm{MO}_{5}$ units with two distinct coordination environments for $\mathrm{Cu}$ and $\mathrm{Zn}$ (Fig. 1a and c). ${ }^{32,33}$ Each $\mathrm{Zn}$ ion in $\alpha$ $\mathrm{Zn}_{2} \mathrm{~V}_{2} \mathrm{O}_{7}$ is coordinated with five oxygen atoms to form a $\mathrm{ZnO}_{5}$ distorted trigonal bipyramid, while the coordination environment of $\mathrm{Cu}$ ions in $\beta-\mathrm{Cu}_{2} \mathrm{~V}_{2} \mathrm{O}_{7}$ is a distorted square pyramid. ${ }^{32,33}$ In turn, in the high temperature polymorphs of $\mathrm{M}_{2} \mathrm{~V}_{2} \mathrm{O}_{7}$ (Fig. $1 \mathrm{~b}$ and $\mathrm{d}$ ), $\mathrm{Zn}$ and $\mathrm{Cu}$ ions have a distorted tetrahedral coordination environment. ${ }^{34,35}$ Monoclinic $\beta-\mathrm{Zn}_{2} \mathrm{~V}_{2} \mathrm{O}_{7}$ has a $\mathrm{V}$ ion occupying the distorted $\mathrm{VO}_{5}$ trigonal bipyramid, while $\mathrm{VO}_{4}$ tetrahedra are found in orthorhombic $\alpha-\mathrm{Cu}_{2} \mathrm{~V}_{2} \mathrm{O}_{7}{ }^{34,35}$

\section{Synthesis}

A deep eutectic solvent is a eutectic mixture of a hydrogen-bond donor and a hydrogen-bond acceptor, typically quaternary ammonium salt choline chloride $\mathrm{C}_{5} \mathrm{H}_{14} \mathrm{ClNO}$ ((2-hydroxyethyl) trimethylammonium chloride, melting point of $\left.302{ }^{\circ} \mathrm{C}\right) .{ }^{26-28}$ Due to hydrogen bonding between choline chloride and the hydrogen-bond donor, the melting point of the mixture is lowered as compared to that of its individual components. ${ }^{26-28}$ In this work, urea (mp $132-135{ }^{\circ} \mathrm{C}$ ) was used as the hydrogenbond donor, which when combined with choline chloride in a molar ratio of $2: 1$ forms a eutectic with a melting point of 30 ${ }^{\circ} \mathrm{C}$, as determined by establishing a solid-liquid binary phase diagram of choline chloride-urea. ${ }^{36}$ Binary transition metal oxides, such as $\mathrm{ZnO}, \mathrm{Cu}_{2} \mathrm{O}$, and $\mathrm{V}_{2} \mathrm{O}_{5}$, exhibit high solubility in the urea : choline eutectic mixture: $1.31 \mathrm{M}$ for $\mathrm{ZnO}$ at $70{ }^{\circ} \mathrm{C}$, $0.189 \mathrm{M}$ for $\mathrm{Cu}_{2} \mathrm{O}$ at $70{ }^{\circ} \mathrm{C}$, and $0.030 \mathrm{M}$ for $\mathrm{V}_{2} \mathrm{O}_{5}$ at $50{ }^{\circ} \mathrm{C}^{37}$ Notably, these solubilities are comparable to that in hydrochloric acid, ${ }^{37}$ thus the deep eutectic solvent can be considered as an environmentally sustainable replacement for corrosive acids in the synthesis of materials. $\mathrm{Cu}_{2} \mathrm{O}$ was utilized for the synthesis of $\beta-\mathrm{Cu}_{2} \mathrm{~V}_{2} \mathrm{O}_{7}$, as opposed to $\mathrm{CuO}$, because the latter has low solubility $(0.00349 \mathrm{M}) \cdot{ }^{37}$ For the synthesis, metal oxide precursors $\mathrm{ZnO}, \mathrm{Cu}_{2} \mathrm{O}$, and $\mathrm{V}_{2} \mathrm{O}_{5}$ were fully dissolved in the urea : choline chloride mixture at $70{ }^{\circ} \mathrm{C}$. According to Abbott et al., $[\mathrm{ZnClO} \cdot \mathrm{urea}]^{-}$and $\left[\mathrm{VO}_{2} \mathrm{Cl}_{2}\right]^{-}$species are present in the eutectic urea : choline chloride mixture upon dissolution of $\mathrm{ZnO}$ and $\mathrm{V}_{2} \mathrm{O}_{5}$ oxides. ${ }^{37}$ We observed that the resulting solutions have distinct colors, probably due to various oxidation states of the metal in the metal complex. The [ $\mathrm{ZnClO} \cdot$ urea $]^{-}$ complex produces a colorless liquid, while the $\left[\mathrm{VO}_{2} \mathrm{Cl}_{2}\right]^{-}$ complex is green, suggesting increased d orbital splitting of $\mathrm{V}^{5+}$ causing a blue-shift of the optical absorption. The colors of $\mathrm{CuO}$ and $\mathrm{Cu}_{2} \mathrm{O}$ dissolved in the urea : choline chloride mixture are light blue and dark blue, respectively, indicating that the oxidation state of copper ions might be the same in the resulting copper oxide solutions. The solutions were then combined and calcined in open crucibles, allowing for the removal of the deep eutectic solvent in the form of gaseous $\mathrm{NH}_{3}, \mathrm{HCl}$, and $\mathrm{CO}_{2}$ followed by crystallization of ternary oxides. Samples were first heated at $230{ }^{\circ} \mathrm{C}$ for $\alpha-\mathrm{Zn}_{2} \mathrm{~V}_{2} \mathrm{O}_{7}$ and $300{ }^{\circ} \mathrm{C}$ for $\beta-\mathrm{Cu}_{2} \mathrm{~V}_{2} \mathrm{O}_{7}$ to remove $\mathrm{NH}_{3}(\mathrm{~g})$ and $\mathrm{HCl}(\mathrm{g})$ and to avoid 
(a) extensive foaming. Formation of crystalline $\mathrm{NH}_{4} \mathrm{Cl}$ in the ventilation system supports the hypothesis. The gas generated from this first heating step made a $\mathrm{pH}$ paper turn dark green and then the liquid sample became a tar-like product, suggesting that a basic mixture of gaseous $\mathrm{NH}_{3}$ and $\mathrm{HCl}$ escaped first and the leftover hydrocarbon was eliminated upon further heating. $\alpha-\mathrm{Zn}_{2} \mathrm{~V}_{2} \mathrm{O}_{7}$ was synthesized at three different calcination temperatures, $500{ }^{\circ} \mathrm{C}, 600^{\circ} \mathrm{C}$ and $700{ }^{\circ} \mathrm{C}$, while calcination at $400{ }^{\circ} \mathrm{C}$ results in an amorphous product. Powder X-ray diffraction peaks are indexed in accordance with $\alpha-\mathrm{Zn}_{2} \mathrm{~V}_{2} \mathrm{O}_{7}$ (ICSD no. 2886) with a minor amount of impurity ( $2 \mathrm{wt} \%)$ of $\mathrm{ZnV}_{2} \mathrm{O}_{6}$ as shown in Fig. 2a. $\beta-\mathrm{Cu}_{2} \mathrm{~V}_{2} \mathrm{O}_{7}$ was synthesized by a similar route, but lower calcination temperatures $\left(400^{\circ} \mathrm{C}\right.$ and $500{ }^{\circ} \mathrm{C}$ ) were employed. Powder X-ray diffraction peaks are indexed to $\beta-\mathrm{Cu}_{2} \mathrm{~V}_{2} \mathrm{O}_{7}$ (ICSD no. 23479) as shown in Fig. 2b. It is notable that $\beta-\mathrm{Cu}_{2} \mathrm{~V}_{2} \mathrm{O}_{7}$ was obtained even at a low temperature of $400{ }^{\circ} \mathrm{C}$, at which crystalline $\alpha-\mathrm{Zn}_{2} \mathrm{~V}_{2} \mathrm{O}_{7}$ was not observed. Moreover, the mild synthetic conditions yield a phase-pure crystalline $\beta-\mathrm{Cu}_{2} \mathrm{~V}_{2} \mathrm{O}_{7}$ unlike a recent report on a solution combustion synthesis, in which $\beta-\mathrm{Cu}_{2} \mathrm{~V}_{2} \mathrm{O}_{7}$ was synthesized at $500{ }^{\circ} \mathrm{C}$ with impurities $\left(3.0 \% \alpha-\mathrm{Cu}_{2} \mathrm{~V}_{2} \mathrm{O}_{7}\right.$ and $\left.6.5 \% \alpha-\mathrm{CuV}_{2} \mathrm{O}_{6}\right){ }^{38}$

The recent work by Söldner et al. reports on a DES-assisted synthesis of spinel-type ferrites $\mathrm{MFe}_{2} \mathrm{O}_{4}(\mathrm{M}=\mathrm{Mg}$, Co and Ni) from stable binary metal oxide precursors, ${ }^{39}$ which normally would require a high annealing temperature for the solid-state reaction to form $\mathrm{MFe}_{2} \mathrm{O}_{4}$. Using a choline chloride and maleic acid mixture as a solvent, ternary ferrites were synthesized at (b)

Space Group: $\mathrm{C} 2 / \mathrm{m}$ $a=6.9324 \AA$ $b=8.4394 \AA$ $c=5.0326 \AA$
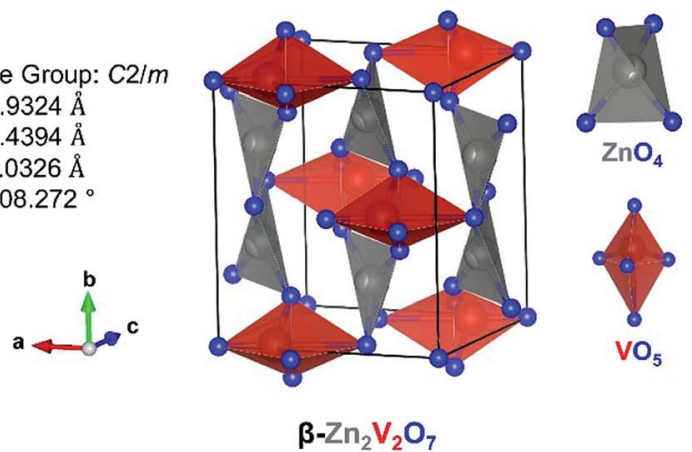

$\mathrm{ZnO}_{4}$

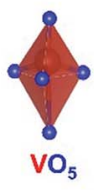

(d)

Space Group: Fdd2
$a=20.6760 \AA$
$b=8.392 \AA$
$c=6.446 \AA$
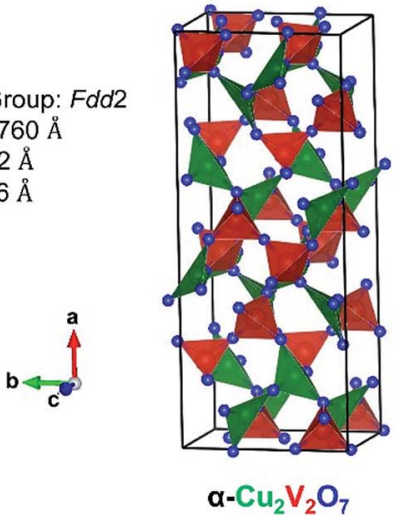
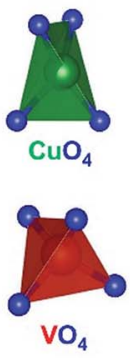

$\alpha-\mathrm{Cu}_{2} \mathrm{~V}_{2} \mathrm{O}_{7}$ $\beta=108.272^{\circ}$ a lower temperature $\left(500{ }^{\circ} \mathrm{C}\right.$ and $\left.600{ }^{\circ} \mathrm{C}\right)$ as compared to the solid-state reaction. ${ }^{39}$ Our results demonstrate that the synthesis route employing the deep eutectic solvent as a reaction medium can be extended to $\mathrm{M}_{2} \mathrm{~V}_{2} \mathrm{O}_{7}(\mathrm{M}=\mathrm{Zn}$ and $\mathrm{Cu})$ systems.

Further insight into thermal stability and optimized synthesis conditions of zinc and copper vanadates was obtained from in situ high-temperature powder X-ray diffraction (HT PXRD) and DSC/TGA. It is crucial to remove the urea : choline mixture before the thermal stability study, so the transformation of oxides is not hindered by the thermal decomposition of the deep eutectic solvent. Thus, the pre-calcined powdered samples were used in these experiments (calcined at $500{ }^{\circ} \mathrm{C}$ for zinc vanadates and 400 ${ }^{\circ} \mathrm{C}$ for copper vanadates). Fig. 3 shows the evolution of powder $\mathrm{X}$ ray diffraction patterns of $\alpha-\mathrm{Zn}_{2} \mathrm{~V}_{2} \mathrm{O}_{7}$ powders upon heating followed by cooling (with a minor impurity of $\mathrm{ZnV}_{2} \mathrm{O}_{6}, \sim 2 \mathrm{wt} \%$ ). Upon heating to $615{ }^{\circ} \mathrm{C}$, no change in PXRD patterns was observed except the shift of Bragg peaks because of the thermal expansion. $\alpha-\mathrm{Zn}_{2} \mathrm{~V}_{2} \mathrm{O}_{7}$ transformed into $\beta-\mathrm{Zn}_{2} \mathrm{~V}_{2} \mathrm{O}_{7}$ above $615{ }^{\circ} \mathrm{C}$ and remained the same until $914^{\circ} \mathrm{C}$, above which the crystalline phase disappeared due to melting. Upon cooling the melt from $955{ }^{\circ} \mathrm{C}, \beta-\mathrm{Zn}_{2} \mathrm{~V}_{2} \mathrm{O}_{7}$ appeared as a main phase below $718{ }^{\circ} \mathrm{C}$ and transformed back to $\alpha-\mathrm{Zn}_{2} \mathrm{~V}_{2} \mathrm{O}_{7}$ at $590^{\circ} \mathrm{C}$. DSC/TGA (Fig. 4) of the same sample corroborated these findings but allowed more accurate determination of the transition temperatures.

Upon heating, the first sharp endothermic peak was observed at $602{ }^{\circ} \mathrm{C}$, which corresponds to the $\alpha \rightarrow \beta$ transformation of 

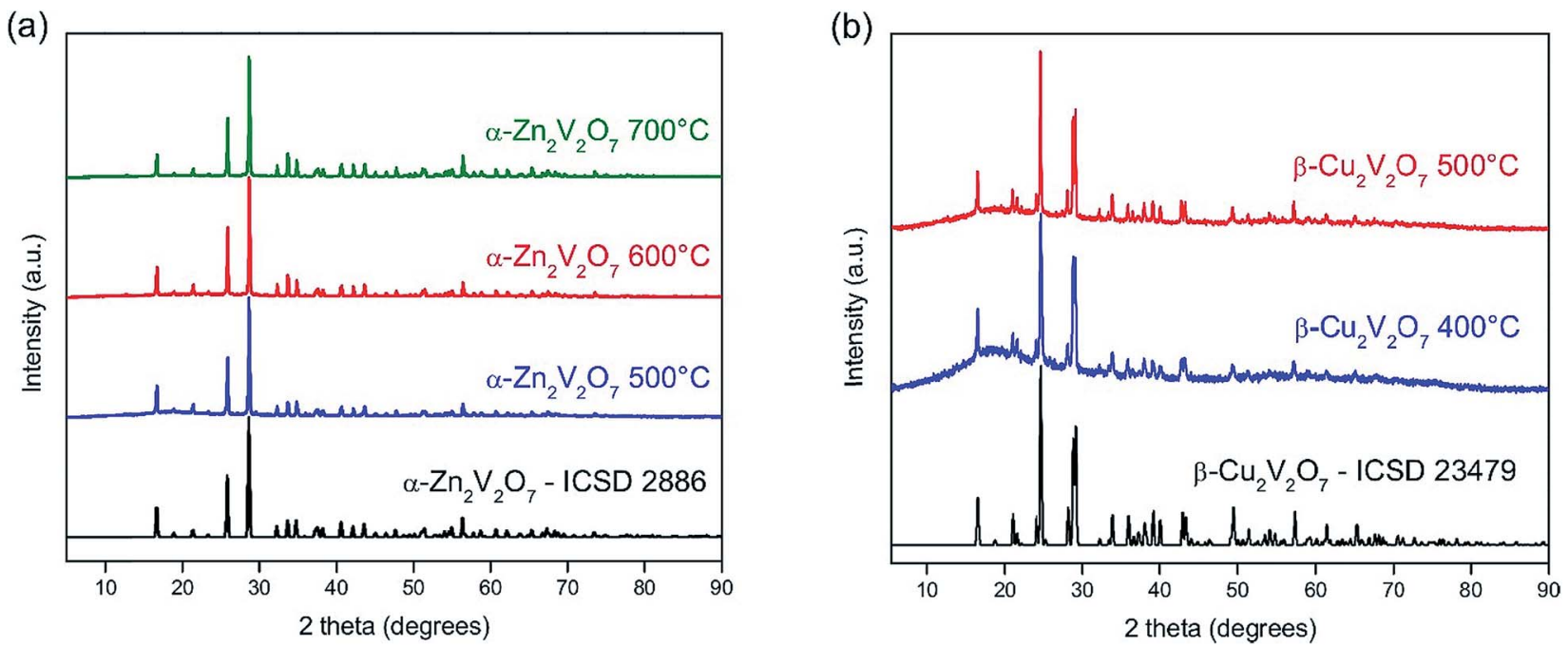

Fig. 2 PXRD patterns of $\alpha-\mathrm{Zn}_{2} \mathrm{~V}_{2} \mathrm{O}_{7}$ synthesized at 500,600 and $700{ }^{\circ} \mathrm{C}$ (a) and $\beta-\mathrm{Cu}_{2} \mathrm{~V}_{2} \mathrm{O}_{7}$ synthesized at 400 and $500{ }^{\circ} \mathrm{C}$ (b) together with calculated patterns using experimentally determined crystal structures. ${ }^{32,33}$

$\mathrm{Zn}_{2} \mathrm{~V}_{2} \mathrm{O}_{7}$. The onset temperature of the second endothermic peak at $850{ }^{\circ} \mathrm{C}$ indicates gradual melting of $\beta-\mathrm{Zn}_{2} \mathrm{~V}_{2} \mathrm{O}_{7}$. Upon cooling, the first exothermic peak was observed at $795{ }^{\circ} \mathrm{C}$, which is due to the formation of crystalline $\beta-\mathrm{Zn}_{2} \mathrm{~V}_{2} \mathrm{O}_{7}$ from the melt. The second exothermic peak at $566{ }^{\circ} \mathrm{C}$ is indicative of the $\beta$ to $\alpha$ phase transformation of $\mathrm{Zn}_{2} \mathrm{~V}_{2} \mathrm{O}_{7}$. The bump from 309 to 533 ${ }^{\circ} \mathrm{C}$ in the DSC curve is due to the sample deposited at the bottom of the crucible, which is in contact with a thermocouple. The deviation of temperatures at which thermal events occurred during the in situ PXRD and DSC/TGA could be due to different heating/cooling rates used during the experiment. We believe that the DSC/TGA curves provide a more accurate temperature of thermal events due to slower heating and cooling rates as well as because the bulk effect is being registered as opposing to HT PXRD results. The phase transformation temperature determined here is in accordance with the phase diagram established

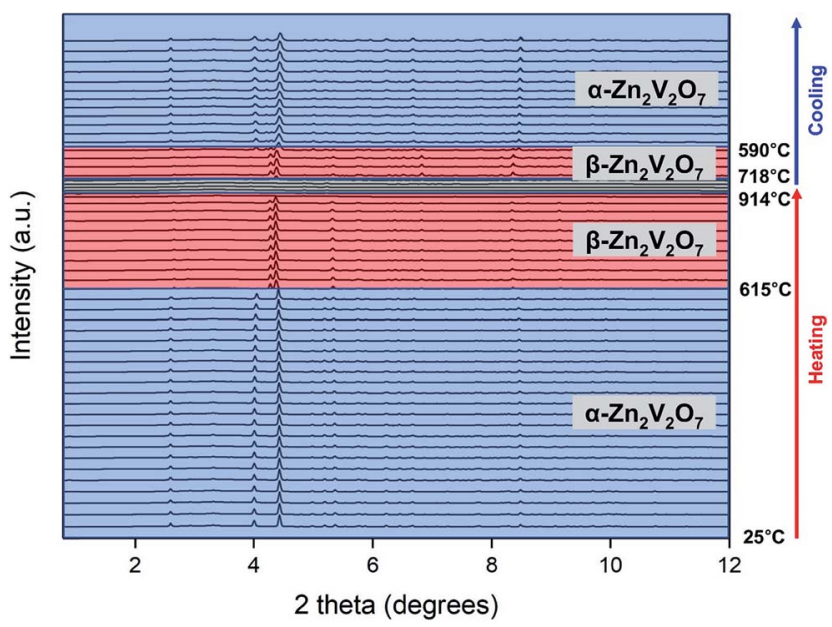

Fig. 3 In situ high-temperature powder X-ray diffraction (HT PXRD) patterns of $\mathrm{Zn}_{2} \mathrm{~V}_{2} \mathrm{O}_{7}$. by Kurzawa et al: $590^{\circ} \mathrm{C}$ for the $\alpha \rightarrow \beta$ transformation and above $855^{\circ} \mathrm{C}$ for the melting of $\beta-\mathrm{Zn}_{2} \mathrm{~V}_{2} \mathrm{O}_{7}{ }^{40}$ Additionally, there was no variation in the TG signal upon heating/cooling of the sample, suggesting that the sample calcined at $500{ }^{\circ} \mathrm{C}$ does not contain any carbon-based impurities from the urea : choline chloride

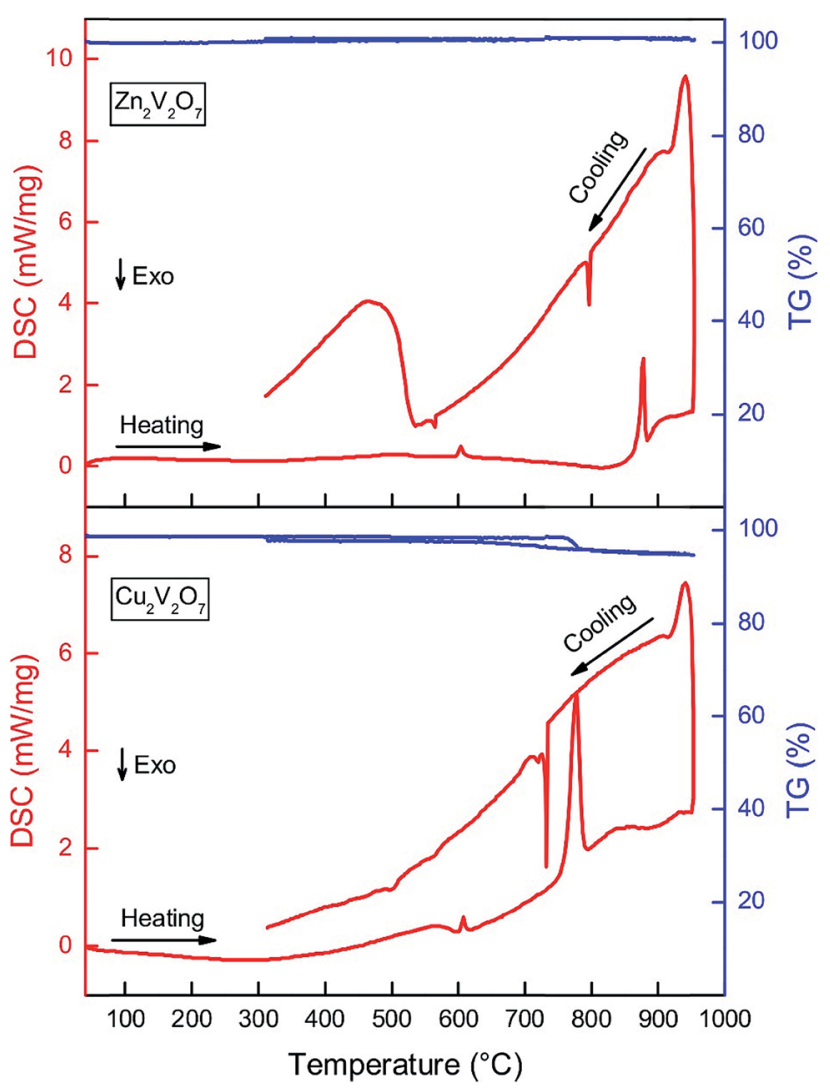

Fig. 4 DSC/TGA of $\alpha-\mathrm{Zn}_{2} \mathrm{~V}_{2} \mathrm{O}_{7}$ (top) and $\beta-\mathrm{Cu}_{2} \mathrm{~V}_{2} \mathrm{O}_{7}$ (bottom) samples measured up to $900{ }^{\circ} \mathrm{C}$. 
mixture. Samples calcined at a lower temperature $\left(350^{\circ} \mathrm{C}\right)$ have about $87 \%$ mass loss and several exothermic peaks between 400 ${ }^{\circ} \mathrm{C}$ and $700{ }^{\circ} \mathrm{C}$ corresponding to the elimination of the carbonbased solvent by a combustion reaction. Thus, the suggested reaction process is as follows:

Heating:

$$
\begin{gathered}
2 \mathrm{ZnO}_{(\text {dissolved })}+\mathrm{V}_{2} \mathrm{O}_{5 \text { (dissolved) }} \stackrel{500{ }^{\circ} \mathrm{C} \& 600{ }^{\circ} \mathrm{C}}{\longrightarrow} \alpha-\mathrm{Zn}_{2} \mathrm{~V}_{2} \mathrm{O}_{7} \\
2 \mathrm{ZnO}_{(\text {dissolved })}+\mathrm{V}_{2} \mathrm{O}_{5 \text { (dissolved) }} \rightarrow \alpha-\mathrm{Zn}_{2} \mathrm{~V}_{2} \mathrm{O}_{7} \stackrel{>602{ }^{\circ} \mathrm{C}}{\longrightarrow} \beta-\mathrm{Zn}_{2} \mathrm{~V}_{2} \mathrm{O}_{7}
\end{gathered}
$$

Cooling:

$$
\beta-\mathrm{Zn}_{2} \mathrm{~V}_{2} \mathrm{O}_{7} \stackrel{566{ }^{\circ} \mathrm{C}}{\longrightarrow} \alpha-\mathrm{Zn}_{2} \mathrm{~V}_{2} \mathrm{O}_{7}
$$

Upon heating, the dissolved oxide precursors react to form $\alpha$ $\mathrm{Zn}_{2} \mathrm{~V}_{2} \mathrm{O}_{7}$, which further transforms into $\beta-\mathrm{Zn}_{2} \mathrm{~V}_{2} \mathrm{O}_{7}$, at $\sim 602{ }^{\circ} \mathrm{C}$. The $\beta$-form is present at a calcination temperature of $700{ }^{\circ} \mathrm{C}(2)$. The $\beta \rightarrow \alpha$ transformation upon natural cooling resulted in $\alpha$ $\mathrm{Zn}_{2} \mathrm{~V}_{2} \mathrm{O}_{7}$ (3). A quenching experiment was performed to stabilize $\beta-\mathrm{Zn}_{2} \mathrm{~V}_{2} \mathrm{O}_{7}$; however, the phase present in the product was $\alpha$ $\mathrm{Zn}_{2} \mathrm{~V}_{2} \mathrm{O}_{7}$.

$\mathrm{Cu}_{2} \mathrm{~V}_{2} \mathrm{O}_{7}$ goes through a more complicated phase transformation and is less thermally stable than $\mathrm{ZnV}_{2} \mathrm{O}_{7}$, as determined by HT PXRD (Fig. S1 $\dagger$ ) and DSC/TGA (Fig. 4). The first endothermic peak of the DSC data was observed at $600{ }^{\circ} \mathrm{C}$, which was attributed to the $\beta \rightarrow \alpha+\gamma$ transformation together with partial decomposition of the $\beta$-phase into $\mathrm{Cu}_{1.5} \mathrm{~V}_{12} \mathrm{O}_{29}$ and presumably amorphous copper oxide. The weak signal (onset temperature of $712{ }^{\circ} \mathrm{C}$ in the DSC data) is due to melting of the $\alpha$-phase, which can be understood by the low enthalpy value from the small amount of the $\alpha$-phase. ${ }^{41}$ The third endothermic peak at $750{ }^{\circ} \mathrm{C}$ corresponds to the melting of the $\gamma$-phase and $\mathrm{Cu}_{1.5} \mathrm{~V}_{12} \mathrm{O}_{29}$, accompanied by $3 \%$ mass loss as evident from TGA data. Since no additional signals were observed in mass spectrum/FTIR data in this temperature range, the mass loss was attributed to oxygen evolution upon melting. Upon cooling, the first exothermic peak at $735^{\circ} \mathrm{C}$ is due to partial crystallization of $\gamma-\mathrm{Cu}_{2} \mathrm{~V}_{2} \mathrm{O}_{7},{ }^{41}$ followed by a weak exothermic peak at $720{ }^{\circ} \mathrm{C}$ from the $\gamma \rightarrow \alpha$ transformation. Interestingly, the sample mass was regained during the crystallization process upon cooling, suggesting that oxygen atoms were restored in the crystal structure. The cooling process is complicated with multiple weak DSC signals between $400{ }^{\circ} \mathrm{C}$ and $600{ }^{\circ} \mathrm{C}$ because $\gamma-\mathrm{Cu}_{2} \mathrm{~V}_{2} \mathrm{O}_{7}$ melts peritectically and low-melting $\beta-\mathrm{Cu}_{2} \mathrm{~V}_{2} \mathrm{O}_{7}, \mathrm{CuVO}_{3}$ and other vanadates containing mono- and divalent copper crystallize. ${ }^{41}$

Scanning electron microscopy (SEM) was used to characterize the morphology and microstructure of $\alpha-\mathrm{Zn}_{2} \mathrm{~V}_{2} \mathrm{O}_{7}$ and $\beta$ $\mathrm{Cu}_{2} \mathrm{~V}_{2} \mathrm{O}_{7}$ samples obtained by calcination at various temperatures (Fig. 5). $\alpha-\mathrm{Zn}_{2} \mathrm{~V}_{2} \mathrm{O}_{7}$ powders have pebble-shaped morphologies with sizes in the ranges $1-3 \mu \mathrm{m}, 2-20 \mu \mathrm{m}$, and $4-$ $20 \mu \mathrm{m}$ for the samples synthesized at $500{ }^{\circ} \mathrm{C}, 600{ }^{\circ} \mathrm{C}$, and $700{ }^{\circ} \mathrm{C}$, respectively. $\beta-\mathrm{Cu}_{2} \mathrm{~V}_{2} \mathrm{O}_{7}$ has a similar particle shape with a size of 0.1-0.5 $\mu \mathrm{m}$ and 1-7 $\mu \mathrm{m}$ for the samples synthesized at $400{ }^{\circ} \mathrm{C}$ and $500{ }^{\circ} \mathrm{C}$, respectively. The average particle sizes were
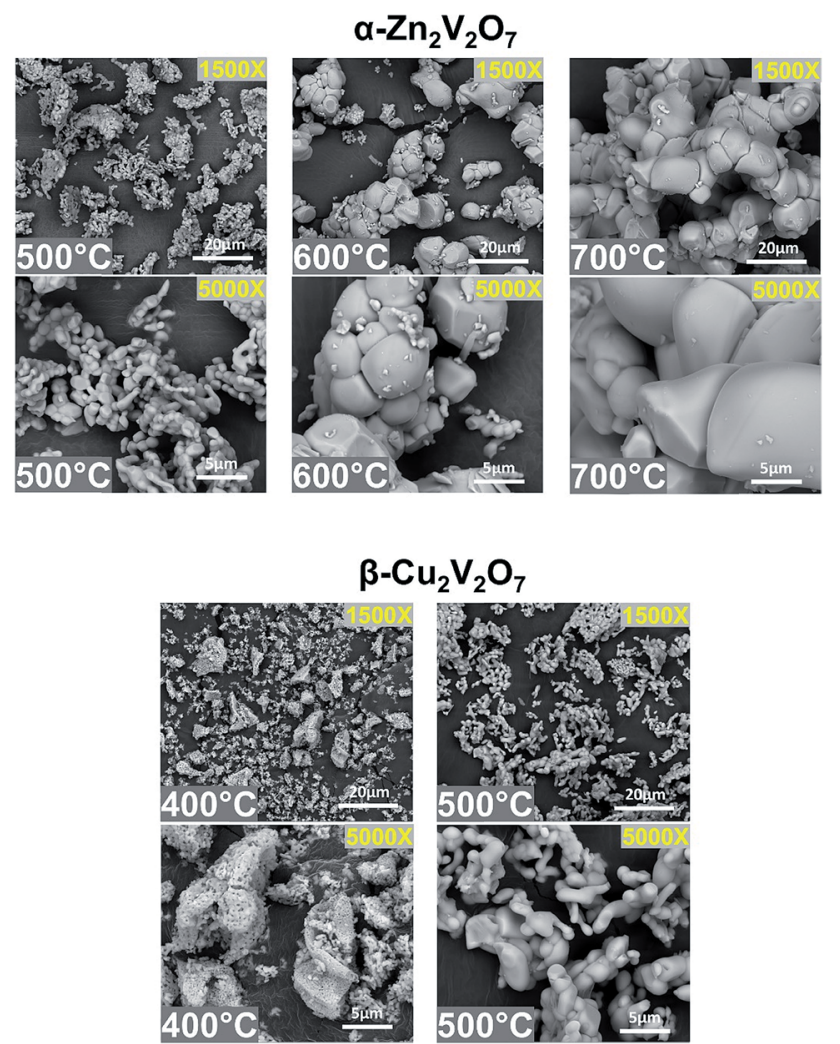

Fig. 5 SEM images of $\alpha-\mathrm{Zn}_{2} \mathrm{~V}_{2} \mathrm{O}_{7}$ calcined at $500{ }^{\circ} \mathrm{C}, 600^{\circ} \mathrm{C}$, and 700 ${ }^{\circ} \mathrm{C}$ (from left to right) and $\beta-\mathrm{Cu}_{2} \mathrm{~V}_{2} \mathrm{O}_{7}$ calcined at $400{ }^{\circ} \mathrm{C}$ and $500{ }^{\circ} \mathrm{C}$ (from left to right).

estimated using the Debye-Scherrer equation, using the full width at half-maximum (FWHM) values of the three most intense diffraction peaks (Table $\mathrm{S} 1 \dagger$ ). Both methods reveal that the particle size increases as the annealing temperature increases from $500{ }^{\circ} \mathrm{C}$ to $600{ }^{\circ} \mathrm{C}$ for $\alpha-\mathrm{Zn}_{2} \mathrm{~V}_{2} \mathrm{O}_{7}$ and from $400{ }^{\circ} \mathrm{C}$ to $500{ }^{\circ} \mathrm{C}$ for $\beta-\mathrm{Cu}_{2} \mathrm{~V}_{2} \mathrm{O}_{7}$. Energy dispersive $\mathrm{X}$-ray spectroscopy (EDS) confirms the absence of metals other than $\mathrm{Cu}, \mathrm{V}$, and $\mathrm{Zn}$, and additionally the $\mathrm{Zn} / \mathrm{V}$ and $\mathrm{Cu} / \mathrm{V}$ ratio was determined to agree with the stoichiometric ratio $2: 2$ (Table $\mathrm{S} 1 \dagger$ ). Thus, higher temperature annealing leads to larger particles without altering the composition.

$\mathrm{X}$-ray photoelectron spectroscopy (XPS) was carried out to understand the chemical composition and the chemical state of metals and oxygen on the surface of $\alpha-\mathrm{Zn}_{2} \mathrm{~V}_{2} \mathrm{O}_{7}$ and $\beta-\mathrm{Cu}_{2} \mathrm{~V}_{2} \mathrm{O}_{7}$. Fig. 6 shows the $\mathrm{O} 1 \mathrm{~s}$ and $\mathrm{V} 2 \mathrm{p}$ core level spectra of $\alpha-\mathrm{Zn}_{2} \mathrm{~V}_{2} \mathrm{O}_{7}$. The $\mathrm{O} 1 \mathrm{~s}$ region is composed of two components, with a narrow peak at $529.7 \mathrm{eV}$ attributed to the lattice oxygen and a broader peak at $531.5 \mathrm{eV}$ due to oxygen defects. ${ }^{\mathbf{4}}$ Interestingly, the concentration of oxygen defects gradually increases as the annealing temperature increases from $500{ }^{\circ} \mathrm{C}$ to $700{ }^{\circ} \mathrm{C}$ (Table 1), suggesting that high temperature annealing under basic conditions with evolution of ammonia promotes oxygen vacancy formation. The two vanadium peaks originate from spin orbit-splitting of $\mathrm{V} 2 \mathrm{p}_{3 / 2}$ and $\mathrm{V} 2 \mathrm{p}_{1 / 2},{ }^{43}$ while each peak is a superposition of two peaks corresponding to $\mathrm{V}^{5+}$ and $\mathrm{V}^{4+}$. Two fitted peaks at $517.1 \mathrm{eV}\left(\mathrm{V} 2 \mathrm{p}_{3 / 2}\right)$ and $524.5 \mathrm{eV}\left(\mathrm{V} 2 \mathrm{p}_{1 / 2}\right)^{43}$ are from 


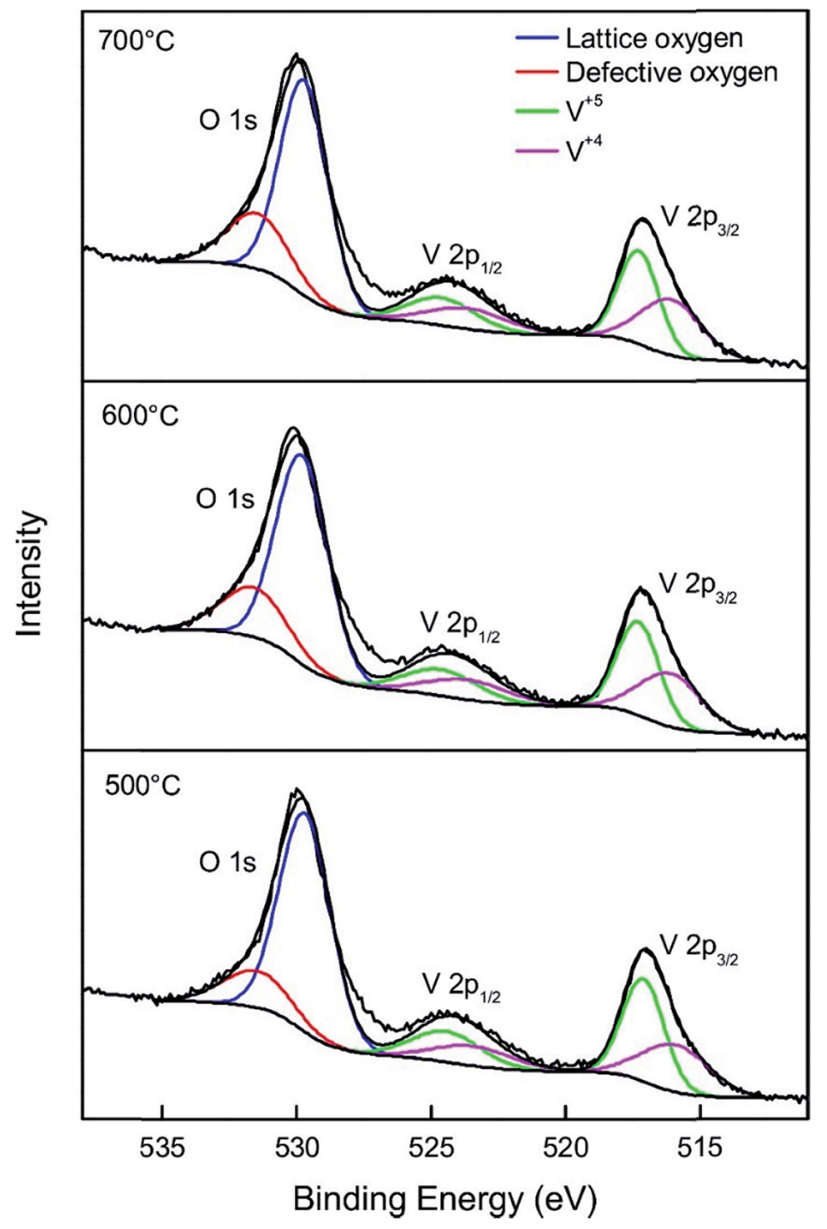

Fig. 6 XPS data of the $O 1$ s and $V 2 p$ regions of $\alpha-Z_{2} V_{2} O_{7}$.

$\mathrm{V}^{5+}$, while peaks located at $515.9 \mathrm{eV}\left(\mathrm{V} 2 \mathrm{p}_{3 / 2}\right)$ and $523.6 \mathrm{eV}\left(\mathrm{V} 2 \mathrm{p}_{1 /}\right.$ $\left.{ }_{2}\right)^{43}$ are attributed to $\mathrm{V}^{4+}$, which needs to be present to compensate the charge imbalance from oxygen vacancies. Unsurprisingly, the concentration of $\mathrm{V}^{4+}$ was the highest in $\alpha$ $\mathrm{Zn}_{2} \mathrm{~V}_{2} \mathrm{O}_{7}$ annealed at $700{ }^{\circ} \mathrm{C}$ (Table 1). Yan et al. and Li et al. also prepared $\alpha-\mathrm{Zn}_{2} \mathrm{~V}_{2} \mathrm{O}_{7}$ and performed XPS analysis, however, only $\mathrm{V}^{5+}$ was identified. ${ }^{25,44}$ Thus, we believe that $\alpha-\mathrm{Zn}_{2} \mathrm{~V}_{2} \mathrm{O}_{7}$ is stable under ultra-high vacuum conditions, and the partial reduction of $\mathrm{V}^{5+}$ stems from the oxygen vacancy created by the synthesis method utilized. Peak positions of $\mathrm{Zn} 2 \mathrm{p}_{3 / 2}$ and $2 \mathrm{p}_{1 / 2}$ are in agreement with those of $\mathrm{ZnO}$ (Fig. S2 $\dagger$ ), ${ }^{43}$ indicating that the divalent oxidation state of zinc remains unchanged due to the completely filled d-subshell.

XPS spectra (Fig. 7) show the chemical states of $\beta-\mathrm{Cu}_{2} \mathrm{~V}_{2} \mathrm{O}_{7}$. The $\mathrm{O}$ 1s core level spectra (Fig. 7a) are identified as the superposition of two peaks located at $529.6 \mathrm{eV}$ and $531.5 \mathrm{eV}$. The narrow peak at $529.6 \mathrm{eV}$ is attributed to lattice oxygen, and the broad peak at $531.5 \mathrm{eV}$ originates from oxygen defects. ${ }^{42}$ It was noticed that the concentration of oxygen defects in $\beta$ $\mathrm{Cu}_{2} \mathrm{~V}_{2} \mathrm{O}_{7}$ shows a similar trend to that in $\alpha-\mathrm{Zn}_{2} \mathrm{~V}_{2} \mathrm{O}_{7}$ : a greater amount of oxygen vacancies was observed in the sample synthesized at a higher temperature (Table 1). The shake-up satellite peaks of Cu 2p (939-944 eV and 958-965 eV) (Fig. 7b), in agreement with the $\mathrm{CuO}$ spectrum, ${ }^{43}$ indicate the presence of $\mathrm{Cu}^{2+}$. Both $2 \mathrm{p}_{3 / 2}$ and $2 \mathrm{p}_{1 / 2}$ peaks of $\mathrm{Cu}$ have a shoulder peak at a lower binding energy ( $931.6 \mathrm{eV}$ and $951.3 \mathrm{eV}$, respectively), which is due to $\mathrm{Cu}^{1+}$ formed to compensate oxygen vacancies. ${ }^{43}$ The concentration of $\mathrm{Cu}^{+}$increases from $\beta-\mathrm{Cu}_{2} \mathrm{~V}_{2} \mathrm{O}_{7}$ synthesized at $400{ }^{\circ} \mathrm{C}$ to $500{ }^{\circ} \mathrm{C}$ due to the greater charge imbalance created by the oxygen defects. Two peaks located at $516.3 \mathrm{eV}$ and $523.8 \mathrm{eV}$ are attributed to $\mathrm{V} 2 \mathrm{p}_{3 / 2}$ and $\mathrm{V} 2 \mathrm{p}_{1 / 2}$ of $\mathrm{V}^{5+}$, respectively (Fig. S3 $\uparrow$ ). ${ }^{43}$ Peak splitting between $\mathrm{V} 2 \mathrm{p}_{3 / 2}$ and $\mathrm{V}$ $2 \mathrm{p}_{1 / 2}$ is about $7.3 \mathrm{eV}$, which agrees with the reported value. ${ }^{43}$ Kim et al. recently prepared $\beta-\mathrm{Cu}_{2} \mathrm{~V}_{2} \mathrm{O}_{7}$ by electrostatic deposition (ESD) and showed the presence of $\mathrm{Cu}^{2+}$ without $\mathrm{Cu}^{+}$in its XPS spectrum. ${ }^{45}$ In addition, the temperature programmed desorption of $\mathrm{O}_{2}$ from $\mathrm{Cu}_{2} \mathrm{~V}_{2} \mathrm{O}_{7}$ performed by Machida et al. reveals that $\beta-\mathrm{Cu}_{2} \mathrm{~V}_{2} \mathrm{O}_{7}$ does not release oxygen until above 600 ${ }^{\circ} \mathrm{C}$ under ultra-high vacuum. ${ }^{46}$ Therefore, we believe that the reduction of $\mathrm{Cu}^{2+}$ is a result of oxygen vacancies created by the basic reaction conditions. Also, due to the fact that the reduction potential of $\mathrm{V}^{5+}$ is higher than that of $\mathrm{Cu}^{2+}$, the charge imbalance was compensated by $\mathrm{Cu}^{+}$, unlike $\mathrm{ZnV}_{2} \mathrm{O}_{7}$ (vide supra).

To further confirm the presence of oxygen-deficient sites in $\beta-\mathrm{Cu}_{2} \mathrm{~V}_{2} \mathrm{O}_{7}$ synthesized at $500{ }^{\circ} \mathrm{C}$, time-of-flight (TOF) neutron powder diffraction $(\lambda=0.8 \AA$ and $2.665 \AA)$ data were collected.

Table 1 Selected XPS data for $\mathrm{M}_{2} \mathrm{~V}_{2} \mathrm{O}_{7}(\mathrm{M}=\mathrm{Zn}$ and $\mathrm{Cu})$

\begin{tabular}{|c|c|c|c|c|}
\hline \multirow[b]{2}{*}{$\mathrm{M}_{2} \mathrm{~V}_{2} \mathrm{O}_{7}$} & \multirow[b]{2}{*}{ Annealing temperature $\left({ }^{\circ} \mathrm{C}\right)$} & \multicolumn{3}{|l|}{ \% concentration } \\
\hline & & Oxygen defects ${ }^{a}$ & $\left(\mathrm{~V}^{4+}\right)^{b}$ & $\left(\mathrm{Cu}^{+}\right)^{c}$ \\
\hline \multirow[t]{3}{*}{$\alpha-\mathrm{Zn}_{2} \mathrm{~V}_{2} \mathrm{O}_{7}$} & 500 & 18.12 & 42.44 & - \\
\hline & 600 & 23.34 & 45.77 & - \\
\hline & 700 & 25.35 & 47.09 & - \\
\hline \multirow[t]{2}{*}{$\beta-\mathrm{Cu}_{2} \mathrm{~V}_{2} \mathrm{O}_{7}$} & 400 & 39.45 & - & 22.67 \\
\hline & 500 & 49.00 & - & 26.22 \\
\hline \multicolumn{5}{|c|}{${ }^{a} \%$ concentration $(\mathrm{O}$ defects $)=\frac{\text { area under the peak with binding energy at } 531.5 \mathrm{eV}}{\text { sum of area under peaks with binding energy at } 531.5 \text { and } 529.7 \mathrm{eV}} \times 100(\%)$. } \\
\hline
\end{tabular}


(a)

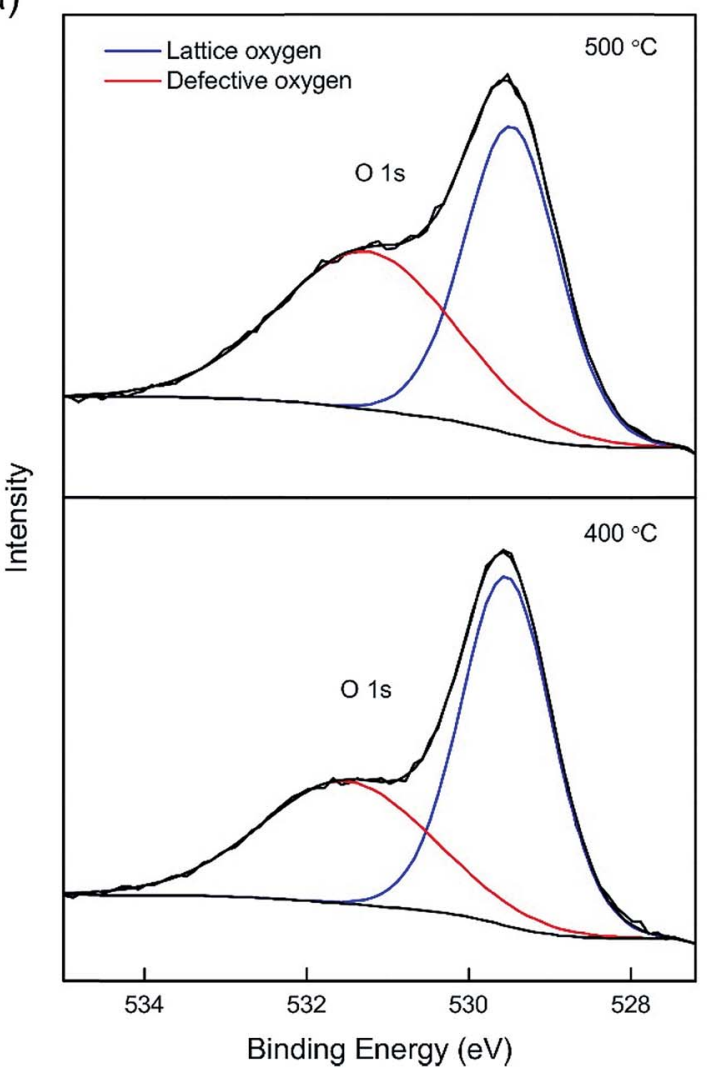

(b)

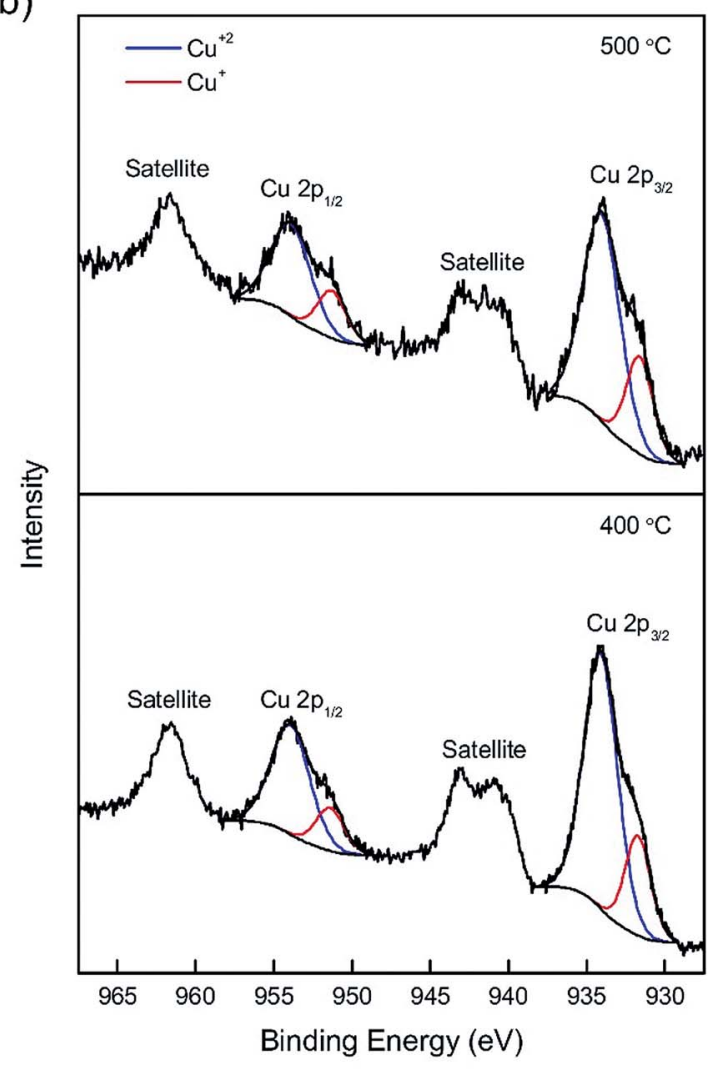

Fig. 7 XPS data of the $\mathrm{Cu} 2 \mathrm{p}$ region (a) and $\mathrm{O} 1 \mathrm{~s}$ region (b) of $\beta-\mathrm{Cu}_{2} \mathrm{~V}_{2} \mathrm{O}_{7}$.

Because of the negative neutron scattering length of vanadium, synchrotron X-ray powder diffraction $(\lambda=0.412749 \AA)$ data were also collected and refined jointly with the neutron diffraction data (Fig. 8). The Rietveld refinement results indicate a phase pure sample of monoclinic $\beta-\mathrm{Cu}_{2} \mathrm{~V}_{2} \mathrm{O}_{7}$. The refinement of atomic displacement parameters (ADPs) for all atoms was carried out isotropically. In addition, site occupancy factors (SOFs) and atomic displacement parameters (ADPs) were refined in separate refinement cycles to prevent correlations for all atomic sites. The refinement of SOFs for metal sites did not result in any deviation from unity. The refinement of SOFs for four crystallographically independent oxygen sites indicates that they are partially occupied with the $\mathrm{O} 4$ sites bearing the largest amount of vacancies (Table 2). The relatively high ADP value for the $\mathrm{O} 1$ site (Table 2) is not from significant thermal motion of oxygen but likely from disordered oxygen ion displacements. ${ }^{47,48}$ All oxygen positions are corner-shared sites of either vanadium or copper centered polyhedra, such as two $\mathrm{VO}_{4}$ tetrahedra sharing $\mathrm{O} 1$ sites. Both $\mathrm{O} 2$ and $\mathrm{O} 3$ are shared between $\mathrm{a}_{\mathrm{VO}_{4}}$ tetrahedron and $\mathrm{a}_{\mathrm{CuO}_{5}}$ distorted square pyramid. One $\mathrm{VO}_{4}$ tetrahedron and two $\mathrm{CuO}_{5}$ distorted square pyramids share the $\mathrm{O} 4$ site. This $\mathrm{O} 4$ site has a higher concentration of oxygen vacancies, in line with its coordination with two mixed valent $\mathrm{Cu}$ centers. Unsurprisingly, the $\mathrm{O} 1$ site, which is coordinated to $\mathrm{V}$ metal centers, has a site fraction close to unity. It should be noted that when the SOF for all O sites is set to 1 , such a refinement resulted in a poorer fit with a high $R_{\mathrm{w}}$ value, thus further confirming the presence of partially occupied oxygen sites. Similar partial occupancies $(\sim 0.95(2))$ for all oxygen sites were obtained, when the ADPs for all four oxygen sites were constrained to be the same and refined to be $0.0120(2) \AA^{2}$. It is noteworthy that the expanded unit cell volume and elongated unit cell parameters $(a, b$, and $c)$ as compared to the reported value $\left(V=581.9 \AA^{3} ; a=7.687(5) \AA, b=8.007(3) \AA\right.$, and $c=10.09$ (2) A from ICSD no. 23479 as compared to unit cell parameters in Table 2) might also be due to the oxygen defects. Similar enlargement of the unit cell volume was reported for vacancy-containing $\mathrm{ZnO}^{49,50}$ and indium-tin-oxide (ITO) thin films. ${ }^{51}$ Moreover, the absence of cation vacancies as confirmed by neutron and synchrotron X-ray diffraction data refinement supports unit cell expansion due to oxygen vacancies.

The composition calculated based on the total oxygen content obtained from the Rietveld refinement is $\mathrm{Cu}_{2} \mathrm{~V}_{2} \mathrm{O}_{6.69(2)}$ (Table 2), which is consistent with $\mathrm{Cu}_{2} \mathrm{~V}_{2} \mathrm{O}_{6.74}$, calculated using the $\mathrm{Cu}^{+}$and $\mathrm{Cu}^{2+}$ ratios from the XPS result and assuming charge balance.

To study the effect of oxygen vacancies and mixed oxidation states of metal centers on the electronic structure, the optical properties of $\alpha-\mathrm{Zn}_{2} \mathrm{~V}_{2} \mathrm{O}_{7}$ and $\beta-\mathrm{Cu}_{2} \mathrm{~V}_{2} \mathrm{O}_{7}$ samples were evaluated from diffuse reflectance UV-vis absorption spectroscopy (Fig. 9). $A$ red shift of the main absorption edge in $\alpha-Z_{2} \mathrm{~V}_{2} \mathrm{O}_{7}$ was observed as the annealing temperature increases: $443.5 \mathrm{~nm}$ for $500{ }^{\circ} \mathrm{C}, 471.6 \mathrm{~nm}$ for $600{ }^{\circ} \mathrm{C}$, and $500.6 \mathrm{~nm}$ for $700{ }^{\circ} \mathrm{C}$. To determine optical indirect band gaps, the data were plotted as 
(a)

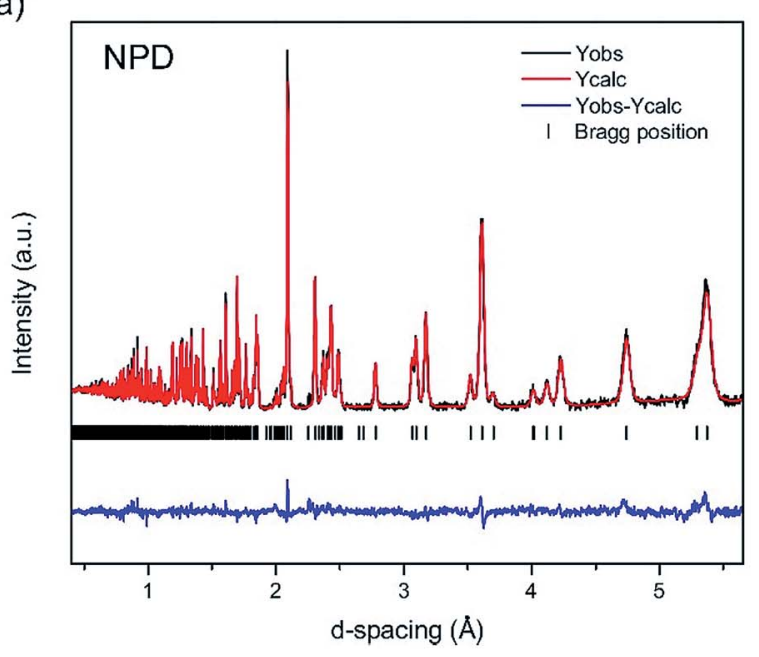

(c)

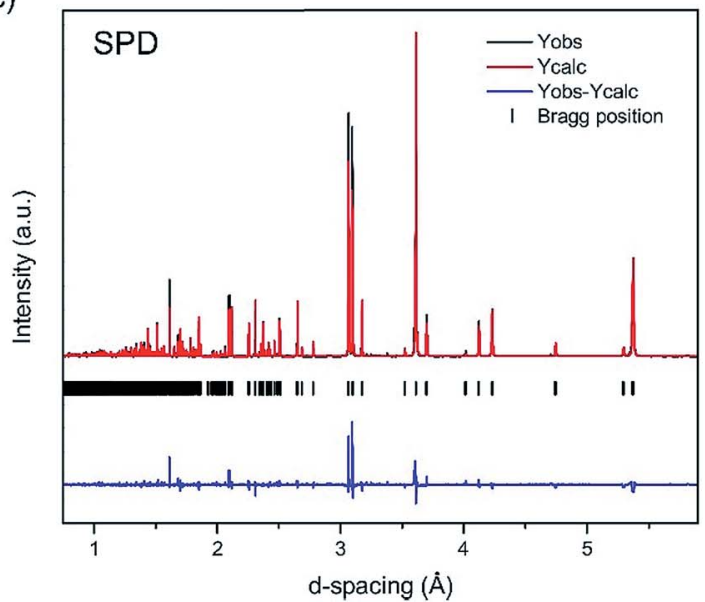

(b)

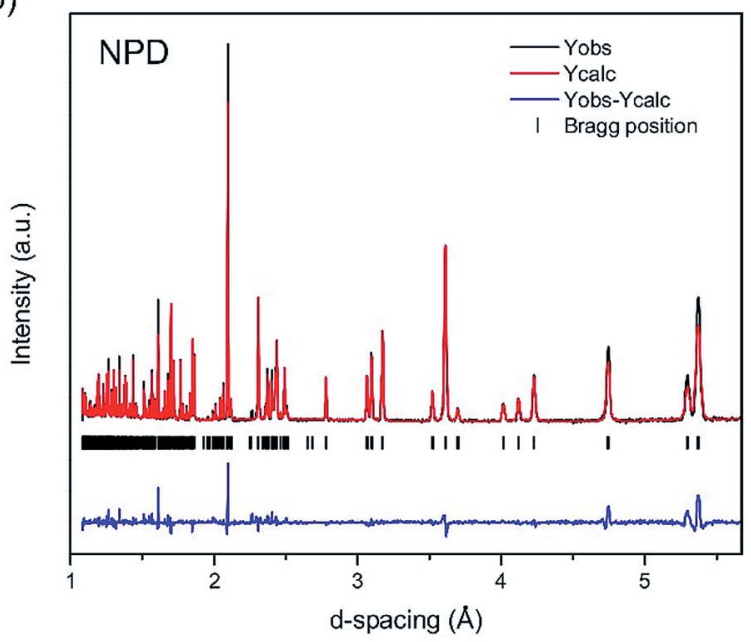

(d)

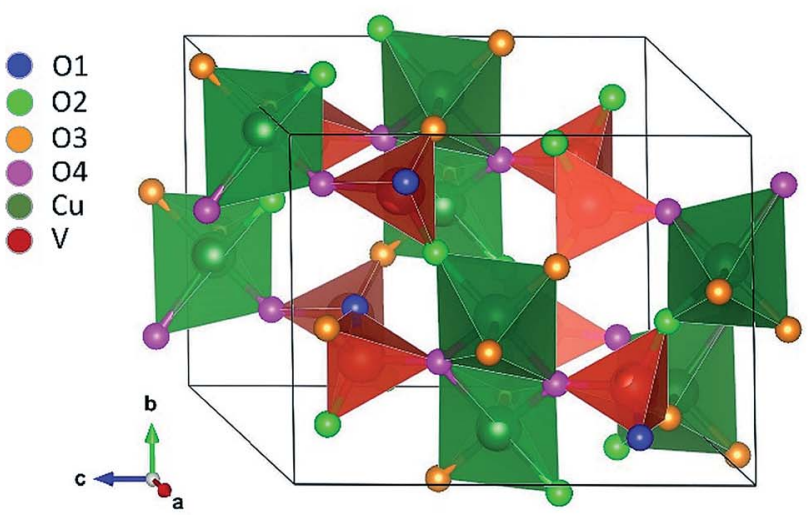

Fig. 8 TOF neutron powder diffraction (NPD) data using (a) $\lambda=0.8 \AA$ and (b) $\lambda=2.665 \AA$ for $\beta-\mathrm{Cu}_{2} \mathrm{~V}_{2} \mathrm{O}_{7}$ synthesized at $500{ }^{\circ} \mathrm{C}$. (c) Synchrotron powder diffraction (SPD) data $(\lambda=0.412749 \AA)$ and (d) crystal structure of $\beta-\mathrm{Cu}_{2} \mathrm{~V}_{2} \mathrm{O}_{7}$.

$(\alpha \times h \nu)^{1 / 2} v s . h \nu$ (Tauc plot), where $\alpha$ is absorbance and $h \nu$ is the excitation energy in eV. The estimated bandgaps are 2.63(3) eV, $2.25(3) \mathrm{eV}$, and $1.97(3) \mathrm{eV}$ for $500{ }^{\circ} \mathrm{C}, 600{ }^{\circ} \mathrm{C}$, and $700{ }^{\circ} \mathrm{C}$, respectively. The bandgap of $\alpha-\mathrm{Zn}_{2} \mathrm{~V}_{2} \mathrm{O}_{7}$ annealed at $500{ }^{\circ} \mathrm{C}$ is close to the reported value $(2.75 \mathrm{eV}),{ }^{25}$ but a smaller bandgap was observed for the samples synthesized at $600{ }^{\circ} \mathrm{C}$ and $700{ }^{\circ} \mathrm{C}$. This is due to oxygen vacancy related disorder being responsible for band tailing. ${ }^{50}$ Interestingly, an additional absorption edge at $682.3 \mathrm{~nm}$ for the $600{ }^{\circ} \mathrm{C}$ annealed sample and $674.7 \mathrm{~nm}$ for the $700{ }^{\circ} \mathrm{C}$ annealed sample is observed, corresponding to mid-

Table 2 Structural results for $\beta-\mathrm{Cu}_{2} \mathrm{~V}_{2} \mathrm{O}_{7}$ from combined Rietveld refinement of neutron powder diffraction and synchrotron powder diffraction data $^{a}$

\begin{tabular}{|c|c|c|c|c|c|c|}
\hline Atom & Wyckoff site & \multicolumn{3}{|c|}{ Coordinates } & $\begin{array}{l}\text { Site occupancy factor } \\
\text { (SOF) }\end{array}$ & $U_{\text {eq. }}, \AA^{2}$ \\
\hline $\mathrm{V}$ & $8 f$ & $0.2753(1)$ & $0.72239(9)$ & $0.21290(8)$ & 1 & $0.0047(2)$ \\
\hline $\mathrm{O} 1$ & $4 e$ & $1 / 2$ & $0.6369(3)$ & $1 / 4$ & $0.999(4)$ & $0.0254(7)$ \\
\hline $\mathrm{O} 2$ & $8 f$ & $0.2666(2)$ & $0.9027(2)$ & $0.1336(2)$ & $0.951(3)$ & $0.0171(5)$ \\
\hline
\end{tabular}

${ }^{a}$ Space group: $C 2 / c, a=7.7014(1) \AA, b=8.03305(4) \AA, c=10.1166(2) \AA, \beta=110.2794(3)^{\circ}, V=587.079(8) \AA^{3}, R_{\mathrm{w}}=9.36 \%, R_{\mathrm{p}}=7.58 \%$, and G.O.F $=$ 3.52 . 
(a)

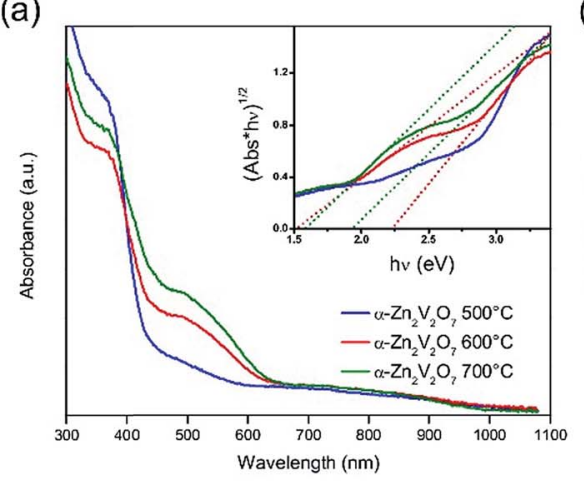

(c)

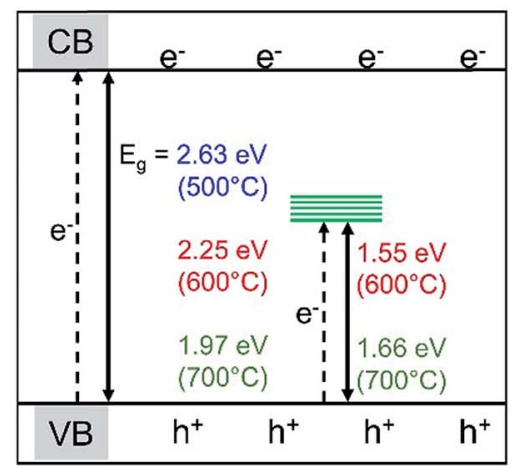

(b)

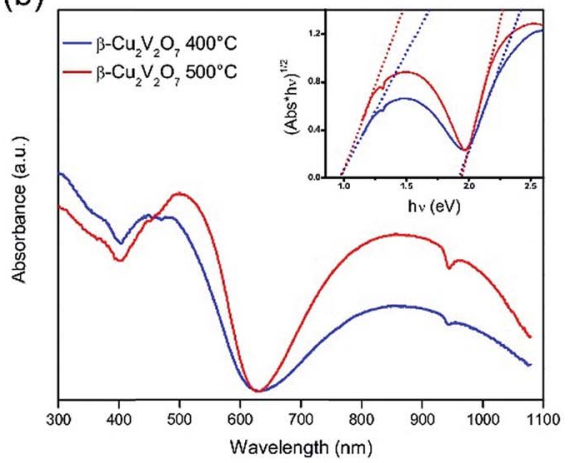

(e)

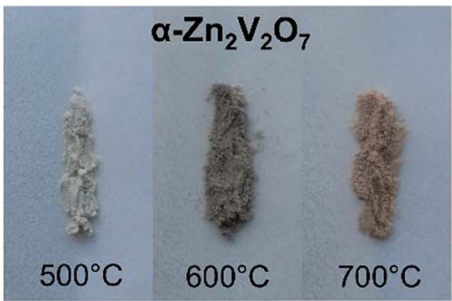

(d)

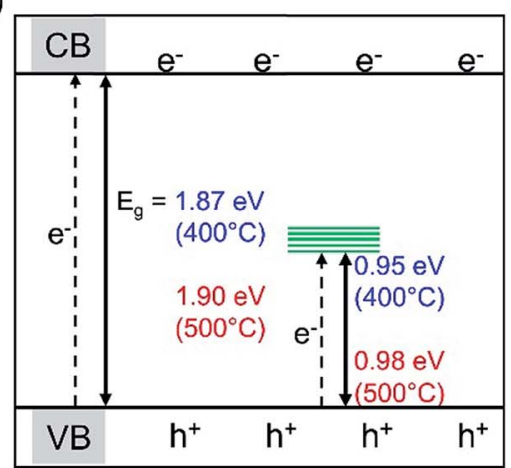

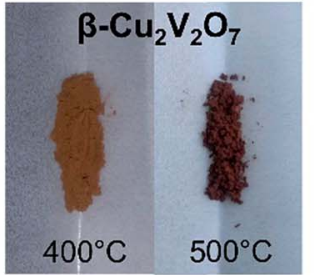

Fig. 9 UV-vis absorption spectra of $\alpha-\mathrm{Zn}_{2} \mathrm{~V}_{2} \mathrm{O}_{7}(\mathrm{a})$ and $\beta-\mathrm{Cu}_{2} \mathrm{~V}_{2} \mathrm{O}_{7}(\mathrm{~b})$. The inset shows Tauc plots and their linear fits (dotted lines) to determine band gaps and mid gaps, corresponding to the additional absorption edge. A schematic of band structures (not to scale) of $\alpha-\mathrm{Zn}_{2} \mathrm{~V}_{2} \mathrm{O}_{7}$ (c) and $\beta$ $\mathrm{Cu}_{2} \mathrm{~V}_{2} \mathrm{O}_{7}(\mathrm{~d})$, showing band gaps and mid-gap states. Optical images of $\alpha-\mathrm{Zn}_{2} \mathrm{~V}_{2} \mathrm{O}_{7}$ and $\beta-\mathrm{Cu}_{2} \mathrm{~V}_{2} \mathrm{O}_{7}$ (e).

gap states at $1.55 \mathrm{eV}$ and $1.66 \mathrm{eV}$, respectively. This additional absorption in the visible-light range is attributed to the d-states from the reduced metal centers $\left(\mathrm{V}^{4+}\right)$ generated to compensate oxygen vacancies. Similar to the band tailing originating from the oxygen defects, ${ }^{50}$ the mid-gap state position changes with different reaction conditions. This could be due to different mid-gap defect densities of the reduced metal centers affecting the bandwidth of the mid-gap states.

UV-vis diffuse reflectance spectra of $\beta-\mathrm{Cu}_{2} \mathrm{~V}_{2} \mathrm{O}_{7}$ show the main absorption edge at $615.0 \mathrm{~nm}$ and $615.5 \mathrm{~nm}$ for the samples synthesized at $400{ }^{\circ} \mathrm{C}$ and $500{ }^{\circ} \mathrm{C}$, respectively (Fig. 9). The estimated band gaps of $1.90(3) \mathrm{eV}\left(400{ }^{\circ} \mathrm{C}\right)$ and $1.87(3) \mathrm{eV}$ $\left(500{ }^{\circ} \mathrm{C}\right.$ ) are smaller than the reported values of $2.20 \mathrm{eV}$ (ref. 52) and $2.22 \mathrm{eV}^{38}$ Similar to $\alpha-\mathrm{Zn}_{2} \mathrm{~V}_{2} \mathrm{O}_{7}$, there is an additional absorption edge at a higher wavelength: $1166.2 \mathrm{~nm}$ for the 400 ${ }^{\circ} \mathrm{C}$ sample and $1150.5 \mathrm{~nm}$ for the $500^{\circ} \mathrm{C}$ sample, corresponding to mid-gap states at $0.95 \mathrm{eV}$ and $0.98 \mathrm{eV}$, respectively. The additional absorption and the distinct color difference between the $400{ }^{\circ} \mathrm{C}$ and $500{ }^{\circ} \mathrm{C}$ samples are due to the mid-gap states located in between the valence band and the conduction band contributed by d-states from the reduced metal centers $\left(\mathrm{Cu}^{+}\right)$. Also, it is observed that the $500{ }^{\circ} \mathrm{C}$ sample exhibits higher absorption in the wavelength range from $700 \mathrm{~nm}$ to $1100 \mathrm{~nm}$ compared to the $400{ }^{\circ} \mathrm{C}$ sample, suggesting that a greater amount of oxygen vacancies is present in the $500{ }^{\circ} \mathrm{C}$ sample, thus a greater fraction of $\mathrm{Cu}^{+}$, consistent with XPS results.
Surface photovoltage spectroscopy (SPS) measurements were conducted to probe the ability of the vanadates to generate and separate photochemical charge carriers. In SPS, the contact potential difference (CPD) of a sample film on top of a conductive substrate is recorded with a contactless Kelvin probe as a function of the incident photon energy (Fig. 10). ${ }^{53-55}$ The change of the CPD under illumination corresponds to a photovoltage. The sign, onset, and size of this voltage provide information about the majority carrier type, the effective band gap, defects, and the photochemistry of the sample, as detailed in previous studies. ${ }^{54-61}$ SPS data for the vanadate powders on FTO substrates are shown in Fig. 10. All samples generate a negative photovoltage caused by majority charge carrier injection into the substrate. This confirms that all vanadates are n-type semiconductors. Using the tangent method, the effective bandgaps are estimated from the major photovoltage feature to be $2.85 \mathrm{eV}, 2.81 \mathrm{eV}$, and $2.95 \mathrm{eV}$ for the $\alpha-\mathrm{Zn}_{2} \mathrm{~V}_{2} \mathrm{O}_{7}$ samples annealed at $500{ }^{\circ} \mathrm{C}, 600^{\circ} \mathrm{C}$ and $700{ }^{\circ} \mathrm{C}$, respectively. These onset values exceed the optical bandgaps of these samples, especially at higher annealing temperatures. The $600{ }^{\circ} \mathrm{C}$ and $700{ }^{\circ} \mathrm{C}$ annealed samples also produce much smaller photovoltages than the $\alpha-\mathrm{Zn}_{2} \mathrm{~V}_{2} \mathrm{O}_{7}$ film annealed at $500{ }^{\circ} \mathrm{C}$. This suggests that the photovoltaic properties of $\alpha-\mathrm{Zn}_{2} \mathrm{~V}_{2} \mathrm{O}_{7}$ are degraded by the higher temperature annealing step. Tentatively, we attribute these observations to electron trapping and/or charge recombination at $1.55 \mathrm{eV}$ and $1.66 \mathrm{eV}$ mid gap states of $\mathrm{V}^{4+}$ that are seen in the optical spectra of the $600{ }^{\circ} \mathrm{C}$ and $700{ }^{\circ} \mathrm{C}$ annealed 
(a)

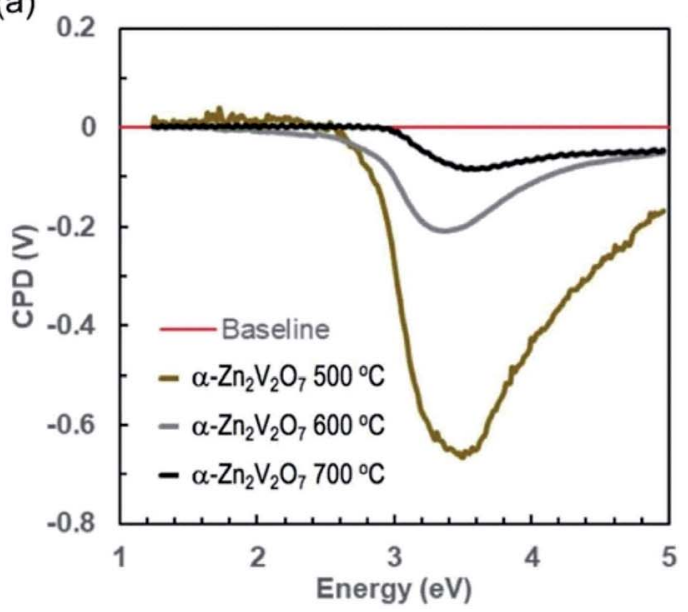

(b)

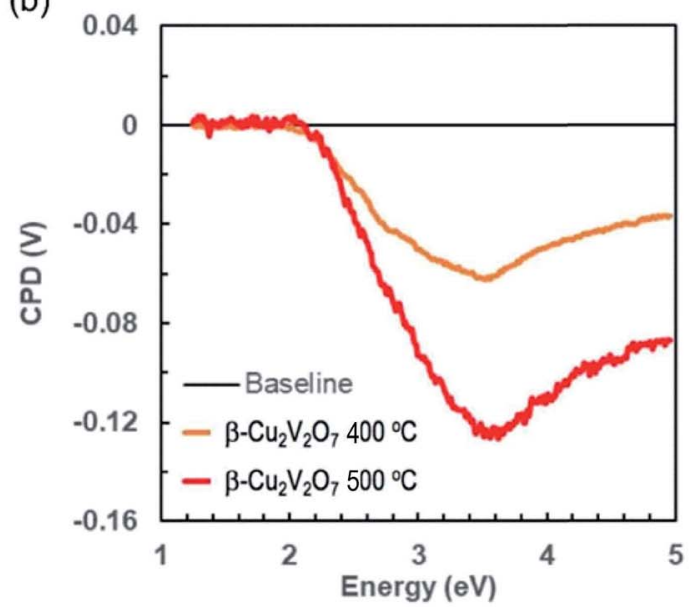

Fig. 10 Surface photovoltage spectra (SPS) of (a) $\alpha-\mathrm{Zn}_{2} \mathrm{~V}_{2} \mathrm{O}_{7}$ and (b) $\beta-\mathrm{Cu}_{2} \mathrm{~V}_{2} \mathrm{O}_{7}$ on FTO substrates in an air atmosphere $\left(\beta-\mathrm{Cu}_{2} \mathrm{~V}_{2} \mathrm{O}_{7}\right)$ and under vacuum $\left(\alpha-\mathrm{Zn}_{2} \mathrm{~V}_{2} \mathrm{O}_{7}\right)$. Contact potential difference (CPD) values are shown relative to those in the dark.

samples. Trap states near the absorber mid gap energy are known to be particularly effective for recombination because they are equally accessible to electrons and holes. ${ }^{62-64}$ The SPS data for copper vanadates on FTO (Fig. 10b) resemble those of zinc vanadates; however, the effective band gap of $2.12 \mathrm{eV}$ for both samples agrees relatively well with the optical band gaps. But again, the photovoltage values achieved with the $400{ }^{\circ} \mathrm{C}$ and $500{ }^{\circ} \mathrm{C}$ annealed copper vanadates $(-0.06 \mathrm{~V}$ and $-0.12 \mathrm{~V}$ at 3.6 $\mathrm{eV}$ ) are much smaller than that for the $500{ }^{\circ} \mathrm{C}$ annealed $\alpha$ $\mathrm{Zn}_{2} \mathrm{~V}_{2} \mathrm{O}_{7}$. The photovoltage appears to be limited by electron trapping and/or recombination at the $0.95 \mathrm{eV} \mathrm{Cu}^{+}$mid gap state. This behavior is analogous to $\mathrm{CuWO}_{4}$, whose photocatalytic properties are also diminished by electron trapping at the $1.8 \mathrm{eV}$ $\mathrm{Cu}^{2+}$ mid gap-state. ${ }^{65}$ Cathodic photocorrosion via electron trapping at copper $\mathrm{d}$ states is a general property of copper containing metal oxides. ${ }^{66-68}$

\section{Conclusion}

Ternary metal oxides $\mathrm{M}_{2} \mathrm{~V}_{2} \mathrm{O}_{7-\delta}(\mathrm{M}=\mathrm{Zn}$ and $\mathrm{Cu})$ were synthesized using a deep eutectic solvent (DES): a urea : choline chloride mixture. Based on thermal stability of the products, their syntheses were optimized. We have shown for the first time the presence of oxygen vacancies and reduced oxidation states of metal ions in ternary metal oxides synthesized by this route. The mixed-valence oxidation states of vanadium $\left(\mathrm{V}^{4+} v s\right.$. $\left.\mathrm{V}^{5+}\right)$ in $\alpha-\mathrm{Zn}_{2} \mathrm{~V}_{2} \mathrm{O}_{7-n}$ and copper $\left(\mathrm{Cu}^{+}\right.$vs. $\left.\mathrm{Cu}^{2+}\right)$ in $\beta-\mathrm{Cu}_{2} \mathrm{~V}_{2} \mathrm{O}_{7-m}$ corroborate partial reduction of the metal ions needed for charge compensation due to the oxygen vacancies. Further investigation of oxygen deficiencies in $\beta-\mathrm{Cu}_{2} \mathrm{~V}_{2} \mathrm{O}_{7-m}$ by neutron powder diffraction reveals that the oxygen site coordinated to two copper metal centers possesses a significant number of oxygen vacancies. By simply changing the annealing temperature of metal precursors in the DES, various concentrations of oxygen vacancies are achieved, thereby tuning the electronic structure of metal oxides. A high concentration of oxygen vacancies in $\mathrm{M}_{2} \mathrm{~V}_{2} \mathrm{O}_{7-\delta}(\mathrm{M}=\mathrm{Zn}$ and $\mathrm{Cu})$ leads to narrowed band gaps and it generates mid-gap states of reduced metal centers in between the valence band and conduction band. Surface photovoltage spectroscopy shows that the mid-gap states reduce the photovoltage of the materials, indicating that $\mathrm{Cu}^{+}$and $\mathrm{V}^{4+}$ ions can serve as electron/hole trap and recombination sites. This limits solar energy conversion applications of the vanadates. Most importantly, the results demonstrate the potential of deep eutectic solvents for the synthesis of semiconducting metal oxides containing oxygen vacancies.

\section{Conflicts of interest}

There are no conflicts to declare.

\section{Acknowledgements}

We thank Dr Kirill Kovnir (Department of Chemistry, Iowa State University and Ames Laboratory) for the access to the PXRD diffractometer; Dr Javier Vela (Department of Chemistry, Iowa State University and Ames Laboratory) for the access to the UVvis spectrometer; Dr Warren Straszheim (Materials Analysis Research Laboratory, Iowa State University) and Tori Cox (Iowa State University) for the help with SEM/EDS data acquisition; Dr Dapeng Jing (Materials Analysis Research Laboratory, Iowa State University) for the help with XPS measurements; Steve Veysey (Chemical Instrumentation Facility, Iowa State University) for the help with DSC/TGA measurements; Dr Ashfia Huq (Oak Ridge National Laboratory) for neutron diffraction data collection; and Dr Wenqian Xu and Dr Andrey Yakovenko at 17BM beamline, APS ANL, and Colin Harmer at Iowa State University for assistance in HT PXRD. The POWGEN beamline at the Spallation Neutron Source, Oak Ridge National Laboratory is sponsored by the Scientific User Facilities Division, Office of Basic Energy Sciences, U.S. Department of Energy. Use of the Advanced Photon Source at Argonne National Laboratory was supported by the U.S. Department of Energy, Office of Science, Office of Basic Energy Sciences, under Contract No. DE-AC02- 
06CH11357. Support for surface photovoltage spectroscopy measurements was provided by the U.S. Department of Energy, Office of Science, Office of Basic Energy Sciences under Award Number DOE-SC0015329.

\section{References}

1 A. Fujishima and K. Honda, Electrochemical Photolysis of Water at a Semiconductor Electrode, Nature, 1972, 238, 3738.

2 K. Sayama and H. Arakawa, Photocatalytic decomposition of water and photocatalytic reduction of carbon dioxide over zirconia catalyst, J. Phys. Chem., 1993, 97, 531-533.

3 K. Sayama and H. Arakawa, Effect of $\mathrm{Na}_{2} \mathrm{CO}_{3}$ addition on photocatalytic decomposition of liquid water over various semiconductor catalysis, J. Photochem. Photobiol., A, 1994, 77, 243-247.

4 K. Sayama and H. Arakawa, Effect of carbonate addition on the photocatalytic decomposition of liquid water over a $\mathrm{ZrO}_{2}$ catalyst, J. Photochem. Photobiol., A, 1996, 94, 67-76.

5 V. R. Reddy, D. W. Hwang and J. S. Lee, Photocatalytic Water Splitting over $\mathrm{ZrO}_{2}$ Prepared by Precipitation Method, Korean J. Chem. Eng., 2003, 20, 1026-1029.

6 J. J. Zou, C. J. Liu and Y. P. Zhang, Control of the MetalSupport Interface of NiO-Loaded Photocatalysts via Cold Plasma Treatment, Langmuir, 2006, 22, 2334-2339.

7 K. Sayama, H. Arakawa and K. Domen, Photocatalytic water splitting on nickel intercalated $\mathrm{A}_{4} \mathrm{Ta}_{x} \mathrm{Nb}_{6-x} \mathrm{O}_{17}(\mathrm{~A}=\mathrm{K}, \mathrm{Rb})$, Catal. Today, 1996, 28, 175-182.

$8 \mathrm{H}$. Kato and A. Kudo, New tantalate photocatalysts for water decomposition into $\mathrm{H}_{2}$ and $\mathrm{O}_{2}$, Chem. Phys. Lett., 1998, 295, 487-492.

9 Y. Takahara, J. N. Kondo, T. Takata, D. Lu and K. Domen, Mesoporous Tantalum Oxide. 1. Characterization and Photocatalytic Activity for the Overall Water Decomposition, Chem. Mater., 2001, 13, 1194-1199.

10 C. Santato, M. Odziemkowski, M. Ulmann and J. Augustynski, Crystallographically Oriented Mesoporous $\mathrm{WO}_{3}$ Films: Synthesis, Characterization, and Applications, J. Am. Chem. Soc., 2001, 123, 10639-10649.

$11 \mathrm{~F}$. E. Osterloh, Inorganic nanostructures for photoelectrochemical and photocatalytic water splitting, Chem. Soc. Rev., 2013, 42, 2294-2320.

12 J. Boltersdorf, I. Sullivan, T. L. Shelton, Z. Wu, M. Gray, B. Zoellner, F. E. Osterloh and P. A. Maggard, Flux Synthesis, Optical and Photocatalytic Properties of n-type $\mathrm{Sn}_{2} \mathrm{TiO}_{4}$ : Hydrogen and Oxygen Evolution under Visible Light, Chem. Mater., 2016, 28, 8876-8889.

13 X. Ma, X. Cui, Z. Zhao, M. A. Melo Jr, E. J. Roberts and F. E. Osterloh, Use of surface photovoltage spectroscopy to probe energy levels and charge carrier dynamics in transition metal (Ni, Cu, Fe, Mn, Rh) doped $\mathrm{SrTiO}_{3}$ photocatalysts for $\mathrm{H}_{2}$ evolution from water, J. Mater. Chem. A, 2018, 6, 5774-5781.

14 Y. Hosogi, Y. Shimodaira, H. Kato, H. Kobayashi and A. Kudo, Role of $\mathrm{Sn}^{2+}$ in the Band Structure of $\mathrm{SnM}_{2} \mathrm{O}_{6}$ and
$\mathrm{Sn}_{2} \mathrm{M}_{2} \mathrm{O}_{7}(\mathrm{M}=\mathrm{Nb}$ and $\mathrm{Ta})$ and Their Photocatalytic Properties, Chem. Mater., 2008, 20, 1299-1307.

15 P. Li, Y. Zhou, W. Tu, Q. Liu, S. Yan and Z. Zou, Direct Growth of $\mathrm{Fe}_{2} \mathrm{~V}_{4} \mathrm{O}_{13}$ Nanoribbons on a Stainless-Steel Mesh for Visible-Light Photoreduction of $\mathrm{CO}_{2}$ into Renewable Hydrocarbon Fuel and Degradation of Gaseous Isopropyl Alcohol, ChemPlusChem, 2013, 78, 274-278.

16 M. S. Wrighton, A. B. Ellis, P. T. Wolczanski, D. L. Morse, H. B. Abrahamson and D. S. Ginley, Strontium titanate photoelectrodes. Efficient photoassisted electrolysis of water at zero applied potential, J. Am. Chem. Soc., 1976, 98(10), 2774-2779.

17 X. Chen, L. Liu, P. Y. Yu and S. S. Mao, Increasing Solar Absorption for Photocatalysis with Black Hydrogenated Titanium Dioxide Nanocrystals, Science, 2011, 331, 746-750.

18 G. Wang, Y. Ling, H. Wang, X. Yang, C. Wang, J. Z. Zhang and Y. Li, Hydrogen-treated $\mathrm{WO}_{3}$ nanoflakes show enhanced photostability, Energy Environ. Sci., 2012, 5, 6180-6187.

19 G. Wang, Y. Ling, X. Lu, F. Qian, Y. Tong, J. Z. Zhang, V. Lordi, C. R. Leao and Y. Li, Computational and Photoelectrochemical Study of Hydrogenated Bismuth Vanadate, J. Phys. Chem. C, 2013, 117, 10957-10964.

20 J. A. Seabold and N. R. Neale, All First Row Transition Metal Oxide Photoanode for Water Splitting Based on $\mathrm{Cu}_{3} \mathrm{~V}_{2} \mathrm{O}_{8}$, Chem. Mater., 2015, 27, 1005-1013.

21 W. Guo, W. D. Chemelewski, O. Mabayoje, P. Xiao, Y. Zhang and C. B. Mullins, Synthesis and Characterization of $\mathrm{CuV}_{2} \mathrm{O}_{6}$ and $\mathrm{Cu}_{2} \mathrm{~V}_{2} \mathrm{O}_{7}$ : Two Photoanode Candidates for Photoelectrochemical Water Oxidation, J. Phys. Chem. C, 2015, 119, 27220-27227.

22 L. Zhou, Q. Yan, A. Shinde, D. Guevarra, P. F. Newhouse, N. Becerra-Stasiewicz, S. M. Chatman, J. A. Haber, J. B. Neaton and J. M. Gregoire, High Throughput Discovery of Solar Fuels Photoanodes in the $\mathrm{CuO}-\mathrm{V}_{2} \mathrm{O}_{5}$ System, Adv. Energy Mater., 2015, 5, 1500968.

23 C. M. Jiang, G. Segev, L. H. Hess, G. Liu, G. Zaborski, F. M. Toma, J. K. Cooper and I. D. Sharp, CompositionDependent Functionality of Copper Vanadate Photoanodes, ACS Appl. Mater. Interfaces, 2018, 10, 1062710633.

24 C. M. Jiang, M. Farmand, C. H. Wu, Y. S. Liu, J. Guo, W. S. Drisdell, J. K. Cooper and I. D. Sharp, Electronic Structure, Optoelectronic Properties, and Photoelectrochemical Characteristics of $\gamma-\mathrm{Cu}_{3} \mathrm{~V}_{2} \mathrm{O}_{8}$ Thin Films, Chem. Mater., 2017, 29, 3334-3345.

25 Y. Yan, Y. Yu, D. Wu, Y. Yang and Y. Cao, $\mathrm{TiO}_{2} /$ vanadate $\left(\mathrm{Sr}_{10} \mathrm{~V}_{6} \mathrm{O}_{25}, \quad \mathrm{Ni}_{3} \mathrm{~V}_{2} \mathrm{O}_{8}, \quad \mathrm{Zn}_{2} \mathrm{~V}_{2} \mathrm{O}_{7}\right) \quad$ heterostructured photocatalysts with enhanced photocatalytic activity for photoreduction of $\mathrm{CO}_{2}$ into $\mathrm{CH}_{4}$, Nanoscale, 2016, 8, 949958.

26 A. P. Abbott, D. Boothby, G. Capper, D. L. Davies and R. K. Rasheed, Deep Eutectic Solvents Formed between Choline Chloride and Carboxylic Acids: Versatile Alternatives to Ionic Liquids, J. Am. Chem. Soc., 2004, 126, 9142-9147. 
27 E. L. Smith, A. P. Abbott and K. S. Ryder, Deep Eutectic Solvents (DESs) and Their Applications, Chem. Rev., 2014, 114, 11060-11082.

28 O. Ciocirlan, O. Iulian and O. Croitoru, Effect of Temperature on the Physico-chemical Properties of Three Ionic Liquids Containing Choline Chloride, Rev. Chim., 2010, 61, 721-723.

29 PDF-2 Database Incorporated into PDXL Program Software, Rigaku, 2018.

30 P. J. Chupas, K. W. Chapman, C. Kurtz, J. C. Hanson, P. L. Lee and C. P. Grey, A versatile sample-environment cell for non-ambient X-ray scattering experiments, J. Appl. Crystallogr., 2008, 41, 822-824.

31 B. H. Toby and R. B. Von Dreele, GSAS-II: the genesis of a modern open-source all purpose crystallography software package, J. Appl. Crystallogr., 2013, 46, 544-549.

32 R. Gopal and C. Calvo, Crystal Structure of $\alpha-\mathrm{Zn}_{2} \mathrm{~V}_{2} \mathrm{O}_{7}$, Can. J. Chem., 1973, 51(7), 1004-1009.

33 D. Mercurio Lavaud and B. Frit, Structure cristalline de la variete haute temperature du pyrovanadate de cuivre: $\mathrm{Cu}_{2} \mathrm{~V}_{2} \mathrm{O}_{7}$ beta, C. R. Seances Acad. Sci., Ser. C, 1973, 277, 1101-1104.

34 T. I. Krasnenko, V. G. Zubkov, A. P. Tjutjunnik, L. V. Zolotukhina and E. F. Vasjutinskaja, Crystal structure of beta' $\mathrm{Zn}_{2} \mathrm{~V}_{2} \mathrm{O}_{7}$, Kristallografiya, 2003, 48, 40-43.

35 P. D. Robinson, J. M. Hughes and M. L. Malinconico, Blossite alpha- $\mathrm{Cu}(2+)_{2} \mathrm{~V}(5+)_{2} \mathrm{O}_{7}$, a new fumarolic sublimate from Izalco Volcano, El Salvador, Am. Mineral., 1987, 72, 397-400.

36 X. Meng, K. Ballerat-Busserolles, P. Husson and J. M. Andanson, Impact of water on the melting temperature of urea + choline chloride deep eutectic solvent, New J. Chem., 2016, 40, 4492-4499.

37 A. P. Abbott, G. Capper, D. L. Davies, K. J. McKenzie and S. U. Obi, Solubility of Metal Oxides in Deep Eutectic Solvents Based on Choline Chloride, J. Chem. Eng. Data, 2006, 51, 1280-1282.

38 M. K. Hossain, P. Sotelo, H. P. Sarker, M. T. Galante, A. Kormányos, C. Longo, R. T. Macaluso, M. N. Huda, C. Janáky and K. Rajeshwar, Rapid One-Pot Synthesis and Photoelectrochemical Properties of Copper Vanadates, ACS Appl. Energy Mater., 2019, 2, 2837-2847.

39 A. Söldner, J. Zach, M. Iwanow, T. Gärtner, M. Schlosser, A. Pfitzner and B. König, Preparation of Magnesium, Cobalt and Nickel Ferrite Nanoparticles from Metal Oxides using Deep Eutectic Solvents, Chem.-Eur. J., 2016, 22, 13108-13113.

40 M. Kurzawa, I. Rychlowska-Himmel, M. Bosacka and A. Blonska-Tabero, Reinvestigation of Phase Equilibria in the $\mathrm{V}_{2} \mathrm{O}_{5}-\mathrm{ZnO}$ System, J. Therm. Anal. Calorim., 2001, 64, 1113-1119.

41 B. V. Slobodin and R. F. Samigullina, Thermoanalytical study of the polymorphism and melting behavior of $\mathrm{Cu}_{2} \mathrm{~V}_{2} \mathrm{O}_{7}$, Inorg. Mater., 2010, 46, 236-241.

42 M. C. Biesinger, B. P. Payne, L. W. M. Lau, A. Gerson and R. S. C. Smart, X-ray photoelectron spectroscopic chemical state quantification of mixed nickel metal, oxide and hydroxide systems, Surf. Interface Anal., 2009, 41, 324-332.

43 M. C. Biesinger, L. W. M. Lau, A. R. Gerson and R. S. C. Smart, Resolving surface chemical states in XPS analysis of first row transition metals, oxides and hydroxides: Sc, Ti, V, Cu and Zn, Appl. Surf. Sci., 2010, 257, 887-898.

44 Y. Li, Y. Teng, Z. Zhang, Y. Feng, P. Xue, W. Tong and W. Liu, Microwave-assisted synthesis of novel nanostructured $\mathrm{Zn}_{3}(\mathrm{OH})_{2} \mathrm{~V}_{2} \mathrm{O}_{7} \cdot 2 \mathrm{H}_{2} \mathrm{O}$ and $\mathrm{Zn}_{2} \mathrm{~V}_{2} \mathrm{O}_{7}$ as electrode materials for supercapacitors, New J. Chem., 2017, 41, 15298-15304.

45 M. Kim, B. Joshi, H. Yoon, T. Y. Ohm, K. Kim, S. S. Al-Deyab and S. S. Yoon, Electrosprayed copper hexaoxodivanadate $\left(\mathrm{CuV}_{2} \mathrm{O}_{6}\right)$ and pyrovanadate $\left(\mathrm{Cu}_{2} \mathrm{~V}_{2} \mathrm{O}_{7}\right)$ photoanodes for efficient solar water splitting, J. Alloys Compd., 2017, 708, 444-450.

46 M. Machida, T. Kawada, H. Yamashita and T. Tajiri, Role of Oxygen Vacancies in Catalytic $\mathrm{SO}_{3}$ Decomposition over $\mathrm{Cu}_{2} \mathrm{~V}_{2} \mathrm{O}_{7}$ in Solar Thermochemical Water Splitting Cycles, J. Phys. Chem. C, 2013, 117, 26710-26715.

47 V. Vibhu, M. R. Suchomel, N. Penin, F. Weill, J.-C. Grenier, J.-M. Bassat and A. Rougier, Structural transformations of the $\mathrm{La}_{2-x} \mathrm{Pr}_{x} \mathrm{NiO}_{4+\delta}$ system probed by high-resolution synchrotron and neutron powder diffraction, Dalton Trans., 2019, 48, 266-277.

48 T. Broux, C. Prestipino, M. Bahout, S. Paofai, E. Elkaïm, V. Vibhu, J.-C. Grenier, A. Rougier, J.-M. Bassat and O. Hernandez, Structure and reactivity with oxygen of $\mathrm{Pr}_{2} \mathrm{NiO}_{4+\delta}$ : an in situ synchrotron X-ray powder diffraction study, Dalton Trans., 2016, 45, 3024-3033.

49 S. Dutta, M. Chakrabarti, S. Chattopadhyay and D. Jana, Defect dynamics in annealed $\mathrm{ZnO}$ by positron annihilation spectroscopy, J. Appl. Phys., 2005, 98, 053513.

50 S. Dutta, S. Chattopadhyay, D. Jana, A. Banerjee, S. Manik, S. K. Pradhan, M. Sutradhar and A. Sarkar, Annealing effect on nano-ZnO powder studied from positron lifetime and optical absorption spectroscopy, J. Appl. Phys., 2006, 100, 114328.

51 H. Kim, C. M. Gilmore, A. Piqué, J. S. Horwitz, H. Mattoussi, H. Murata, Z. H. Kafafi and D. B. Chrisey, Electrical, optical, and structural properties of indium-tin-oxide thin films for organic light-emitting devices, J. Appl. Phys., 1999, 86, 6451.

52 I. Khan and A. Qurashi, Shape Controlled Synthesis of Copper Vanadate Platelet Nanostructures, Their Optical Band Edges, and Solar-Driven Water Splitting Properties, Sci. Rep., 2017, 7, 14370.

53 L. Kronik and Y. Shapira, Surface Photovoltage Phenomena: Theory, Experiment, and Applications, Surf. Sci. Rep., 1999, 37(1-5), 1-206.

54 T. Dittrich, S. Fiechter and A. Thomas, Surface photovoltage spectroscopy of carbon nitride powder, Appl. Phys. Lett., 2011, 99(8), 084105.

55 D. Gross, I. Mora-Sero, T. Dittrich, A. Belaidi, C. Mauser, A. J. Houtepen, E. Da Como, A. L. Rogach and J. Feldmann, Charge Separation in Type II Tunneling Multi layered Structures of CdTe and CdSe Nanocrystals Directly 
Proven by Surface Photovoltage Spectroscopy, J. Am. Chem. Soc., 2010, 132(17), 5981-5983.

56 B. A. Nail, J. M. Fields, J. Zhao, J. Wang, M. J. Greaney, R. L. Brutchey and F. E. Osterloh, Nickel Oxide Particles Catalyze Photochemical Hydrogen Evolution from WaterNanoscaling Promotes P-Type Character and Minority Carrier Extraction, ACS Nano, 2015, 9(5), 5135-5142.

57 Y. Yang, J. Wang, J. Zhao, B. A. Nail, X. Yuan, Y. Guo and F. E. Osterloh, Photochemical Charge Separation at Particle Interfaces: The n-BiVO ${ }_{4}-\mathrm{p}$-Silicon System, ACS Appl. Mater. Interfaces, 2015, 10(7), 5959-5964.

58 J. Wang, J. Zhao and F. E. Osterloh, Photochemical Charge Transfer Observed in Nanoscale Hydrogen Evolving Photocatalysts Using Surface Photovoltage Spectroscopy, Energy Environ. Sci., 2015, 8, 2970-2976.

59 J. Zhao and F. E. Osterloh, Photochemical Charge Separation in Nanocrystal Photocatalyst Films - Insights from Surface Photovoltage Spectroscopy, J. Phys. Chem. Lett., 2014, 5, 782-786.

60 J. Zhao, B. A. Nail, M. A. Holmes and F. E. Osterloh, Use of Surface Photovoltage Spectroscopy to Measure Built-in Voltage, Space Charge Layer Width, and Effective Band Gap in CdSe Quantum Dot Films, J. Phys. Chem. Lett., 2016, 3335-3340.

61 M. A. Melo, Z. Wu, B. A. Nail, A. T. De Denko, A. F. Nogueira and F. E. Osterloh, Surface Photovoltage Measurements on a Particle Tandem Photocatalyst for Overall Water Splitting, Nano Lett., 2018, 18(2), 805-810.

62 T. Dittrich, Materials concepts for solar cells, Imperial College Press, London, 2015, p. xxxiii, 516 pages.

63 J. Nelson, The Physics of Solar Cells, Imperial College Press, London, 2004, p. 363.

64 P. Würfel, Physics of Solar Cells, Wiley-VCH, Weinheim, 2005, p. 244.

65 Z. Wu, Z. Zhao, G. Cheung, R. M. Doughty, A. R. BallestasBarrientos, B. Hirmez, R. Han, T. Maschmeyer and F. E. Osterloh, Role of Surface States in Photocatalytic Oxygen Evolution with $\mathrm{CuWO}_{4}$ Particles, J. Electrochem. Soc., 2019, 166(5), H3014-H3019.

66 A. Paracchino, N. Mathews, T. Hisatomi, M. Stefik, S. D. Tilley and M. Gratzel, Ultrathin films on copper(I) oxide water splitting photocathodes: a study on performance and stability, Energy Environ. Sci., 2012, 5(9), 8673-8681.

67 G. Sharma, Z. Zhao, P. Sarker, B. A. Nail, J. Wang, M. Huda and F. Osterloh, Electronic structure, photovoltage, and photocatalytic hydrogen evolution with $\mathrm{p}-\mathrm{CuBi}_{2} \mathrm{O}_{4}$ nanocrystals, J. Mater. Chem. A, 2016, 4, 2936-2942.

68 U. A. Joshi and P. A. Maggard, $\mathrm{CuNb}_{3} \mathrm{O}_{8}$ : A p-Type Semiconducting Metal Oxide Photoelectrode, J. Phys. Chem. Lett., 2012, 3(11), 1577-1581. 